\title{
MAX-DOAS formaldehyde slant column measurements during CINDI: intercomparison and analysis improvement
}

\author{
G. Pinardi ${ }^{1}$, M. Van Roozendael ${ }^{1}$, N. Abuhassan ${ }^{4}$, C. Adams ${ }^{2}$, A. Cede ${ }^{4}$, K. Clémer ${ }^{1,}{ }^{*}$, C. Fayt $^{1}$, U. Frieß ${ }^{5}$, M. Gil ${ }^{6}$,

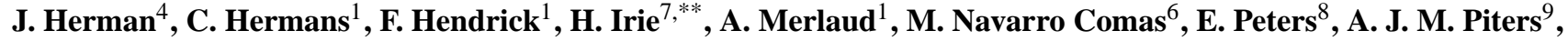 \\ O. Puentedura ${ }^{6}$, A. Richter ${ }^{8}$, A. Schönhardt ${ }^{8}$, R. Shaiganfar ${ }^{3}$, E. Spinei ${ }^{10}$, K. Strong ${ }^{2}$, H. Takashima ${ }^{7}{ }^{* * * *}$, \\ M. Vrekoussis ${ }^{8,11}$, T. Wagner ${ }^{3}$, F. Wittrock ${ }^{8}$, and S. Yilmaz ${ }^{5}$ \\ ${ }^{1}$ Department of Physics, University of Toronto, Ontario, Canada \\ ${ }^{2}$ BIRA-IASB - Belgian Institute for Space Aeronomy, Brussels, Belgium \\ ${ }^{3}$ Max Planck Institute for Chemistry, Mainz, Germany \\ ${ }^{4}$ NASA/Goddard Space Flight Center, GSFC, Greenbelt, MD, USA \\ ${ }^{5}$ Institute of Environmental Physics, University of Heidelberg, Heidelberg, Germany \\ ${ }^{6}$ National Institute for Aerospace technology, INTA, Madrid, Spain \\ ${ }^{7}$ Research Institute for Global Change, JAMSTEC, Yokohama, Japan \\ ${ }^{8}$ Institute of Environmental Physics, University of Bremen, Bremen, Germany \\ ${ }^{9}$ Royal Netherlands Meteorological Institute, KNMI, De Bilt, The Netherlands \\ ${ }^{10}$ Laboratory for Atmospheric Research, Washington State University, Pullman, WA, USA \\ ${ }^{11}$ Energy, Environment and Water Research Center, The Cyprus Institute, Nicosia, Cyprus \\ *now at: Instituut voor Sterrenkunde, Katholieke Universiteit Leuven, Leuven, Belgium \\ ** now at: Center for Environmental Remote Sensing, Chiba University, Chiba, Japan \\ *** now at: Department of Earth System Science, Faculty of Science, Fukuoka University, Fukuoka, Japan
}

Correspondence to: G. Pinardi (gaia.pinardi@aeronomie.be)

Received: 23 July 2012 - Published in Atmos. Meas. Tech. Discuss.: 18 September 2012

Revised: 12 December 2012 - Accepted: 3 January 2013 - Published: 31 January 2013

\begin{abstract}
We present intercomparison results for formaldehyde (HCHO) slant column measurements performed during the Cabauw Intercomparison campaign of Nitrogen Dioxide measuring Instruments (CINDI) that took place in Cabauw, the Netherlands, in summer 2009. During two months, nine atmospheric research groups simultaneously operated MAXDOAS (MultiAXis Differential Optical Absorption Spectroscopy) instruments of various designs to record UVvisible spectra of scattered sunlight at different elevation angles that were analysed using common retrieval settings. The resulting $\mathrm{HCHO}$ data set was found to be highly consistent, the mean difference between instruments generally not exceeding $15 \%$ or $7.5 \times 10^{15}$ molec $\mathrm{cm}^{-2}$, for all viewing elevation angles. Furthermore, a sensitivity analysis was performed to investigate the uncertainties in the HCHO slant column retrieval when varying key input parameters such as the molecular absorption cross sections, correction terms
\end{abstract}

for the Ring effect or the width and position of the fitting interval. This study led to the identification of potentially important sources of errors associated with crosscorrelation effects involving the Ring effect, $\mathrm{O}_{4}, \mathrm{HCHO}$ and $\mathrm{BrO}$ cross sections and the DOAS closure polynomial. As a result, a set of updated recommendations was formulated for HCHO slant column retrieval in the $336.5-359 \mathrm{~nm}$ wavelength range. To conclude, an error budget is proposed which distinguishes between systematic and random uncertainties. The total systematic error is estimated to be of the order of $20 \%$ and is dominated by uncertainties in absorption cross sections and related spectral cross-correlation effects. For a typical integration time of one minute, random uncertainties range between 5 and $30 \%$, depending on the noise level of individual instruments. 


\section{Introduction}

Formaldehyde (HCHO) is the most abundant organic carbonyl compound in the atmosphere. Being a short-lived oxidation product of a large number of volatile organic compounds (VOCs), its abundance can be closely related to VOC emissions of natural origin or from human activities. In particular, the variability of $\mathrm{HCHO}$ over continents is dominated by local production from non-methane volatile organic compounds (NMVOCs) (Millet et al., 2006; Stavrakou et al., 2009a,b and references therein), originating from biogenic, pyrogenic or anthropogenic sources. These emissions, through their involvement in tropospheric ozone chemistry, are important in controlling air quality. Over Europe, satellite observations reveal a marked seasonal cycle, with a summer maximum and a winter minimum (Curci et al., 2010).

Tropospheric formaldehyde has been observed from nadir UV backscatter satellite sensors (Chance et al., 2000; Palmer et al., 2003; Wittrock et al., 2006; De Smedt et al., 2008, 2010; Millet et al., 2008; Marbach et al., 2009; Vrekoussis et al., 2010; Curci et al., 2010), as well as from airborne and ground-based in situ instruments (e.g. Hak et al., 2005; Fried et al., 2011 and references therein) and groundbased remote-sensing Fourier transform infrared spectrometers (e.g. Demoulin et al., 1999; Jones et al., 2009; Vigouroux et al., 2009). In the UV, HCHO can be measured using active and passive Differential Optical Absorption Spectroscopy (DOAS) (see Platt and Stutz, 2008, for a review). Among the category of passive DOAS systems, the Multiaxis DOAS (MAX-DOAS) technique can be used for tropospheric trace gas monitoring (Van Roozendael et al., 2003; Hönninger et al., 2004; Sinreich et al., 2005). The MAX-DOAS technique has been successfully applied to $\mathrm{NO}_{2}, \mathrm{HCHO}, \mathrm{SO}_{2}, \mathrm{BrO}$, and CHOCHO detection (e.g. Bobrowski et al., 2003; Wittrock et al., 2004; Heckel et al., 2005; Sinreich et al., 2007; Pikelnaya et al., 2007; Theys et al., 2007; Clémer et al., 2009; Vlemmix et al., 2010, 2011a; Irie et al., 2011; Wagner et al., 2011).

MAX-DOAS instruments perform quasi-simultaneous observations of scattered sunlight in a range of viewing directions scanned from the horizon to the zenith. Measurements made at low elevation angles have a higher sensitivity to lower tropospheric layers, since in this geometry the photons travel longer paths through these layers than photons sampled at larger elevation angles. This results in an increased sensitivity to atmospheric absorbers that are located near the surface, such as HCHO. It has been shown that the MAXDOAS technique can be used to to retrieve information on the vertical distribution of both trace gases and aerosols (Wagner et al., 2004; Frieß et al., 2006; Irie et al., 2008, 2009; Clémer et al., 2010; Li et al., 2010). These advantages, combined with the fact that measurements can be made automatically year-round, with a good/frequent temporal sampling, make the MAX-DOAS method suitable for long-term monitoring of atmospheric composition. Moreover, due to their spatial representativeness in both vertical and horizontal axes (Irie et al., 2011; Wagner et al., 2011), MAX-DOAS measurements are also particularly well suited to make the link between satellite observations, chemical transport model calculations, and in situ measurements in a validation context (Brinksma et al., 2008; Vlemmix et al., 2011b).

The first reported MAX-DOAS measurements of HCHO were performed in the Italian Po Valley, in summers 2002 and 2003 (Heckel et al., 2005; Wagner et al., 2011). Soon after, Hak et al. (2005) reported on an intercomparison exercise including the chromatographic technique, long-path (LP) DOAS, Fourier Transform InfraRed (FTIR), MAXDOAS, and Hantzsch-type in situ instruments, showing good consistency between the different techniques. In 2006, Wittrock et al. published a study on global HCHO mapping from the SCIAMACHY (SCanning Imaging Absorption spectroMeter for Atmospheric CHartographY) nadir satellite instrument including comparisons with two MAX-DOAS systems (in Kenya and the Netherlands), and found good agreement within the estimated uncertainties. Pikelnaya et al. (2007) and Inomata et al. (2008) also compared MAXDOAS HCHO with LP-DOAS and PTR-MS data, respectively, and Vigouroux et al. (2009) compared SCIAMACHY, MAX-DOAS and FTIR HCHO total columns in a tropical remote region. Recently, Fried et al. (2011) presented a comparison of ground-based MAX-DOAS and aircraft HCHO measurements during the INTEX-B (INtercontinental chemical Transport EXperiment) campaign and showed good agreement between both data sets.

Although the aforementioned studies have largely demonstrated the capabilities of MAX-DOAS systems for HCHO detection, no effort has been devoted so far to intercompare and harmonize instruments and retrieval methods. Such activities are an essential prerequisite for the reliable retrieval of vertical columns and profiles from MAX-DOAS HCHO measurements. The Cabauw Intercomparison campaign of Nitrogen Dioxide measuring Instruments (CINDI) in the Netherlands in June-July 2009 (Roscoe et al., 2010; Piters et al., 2012), where a number of MAX-DOAS instruments were jointly operated, presented the opportunity to assess for the first time the consistency of these HCHO measuring systems. The Cabauw site is located in a semi-rural area of the Netherlands where formaldehyde concentrations are expected to be between one and several tens of ppbv, which are typical background levels in the continental boundary layer and urban regions, respectively (Hak et al., 2005; Fried et al., 2011). In their study on multi-component MAX-DOAS retrievals during CINDI, Irie et al. (2011) reported median HCHO vertical mixing ratios (VMRs) of around $2.5 \mathrm{ppbv}$, and peak values of up to $8 \mathrm{ppbv}$. The CINDI data set is therefore ideally suited for an HCHO intercomparison exercise.

This paper is structured as follows. Section 2 gives an overview of the CINDI campaign, the data recorded, the instruments, and the settings used by the different groups. Results from the HCHO slant column intercomparison are then presented in Sect. 3. In Sect. 4, we focus on sensitivity tests 
performed to assess the stability of the $\mathrm{HCHO}$ retrievals. Results are used to derive an error budget for slant column retrievals. Conclusions and perspectives are given in Sect. 5.

\section{Data analysis}

\subsection{The CINDI intercomparison campaign}

The CINDI campaign took place at the Cabauw Experimental Site for Atmospheric Research (CESAR site; Russchenberg et al., 2005), a semi-rural area in the Netherlands. Although the campaign mainly focused on tropospheric $\mathrm{NO}_{2}$, aerosols were also monitored with in situ systems, sun photometers and a lidar (Piters et al., 2012; Zieger et al., 2011; Irie et al., 2011). To complement the atmospheric composition measurements, the site offered a large ensemble of meteorological observations. A detailed description of the CINDI campaign and an overview of first results can be found in Piters et al. (2012).

Instruments were installed and tested between 8 and 14 June 2009 and a formal semi-blind intercomparison of $\mathrm{NO}_{2}$ and $\mathrm{O}_{4}$ Differential Slant Column Densities (DSCDs) took place from 15 to 30 June 2009 (Roscoe et al., 2010). After that date, additional measurements were performed by several groups until 24 July, focusing on other species, such as $\mathrm{HCHO}, \mathrm{BrO}$, and $\mathrm{CHOCHO}$. The goal of the formal semi-blind $\mathrm{NO}_{2}$ and $\mathrm{O}_{4}$ intercomparison was to characterize the current level of consistency of multi-axis instruments, as previously done for the zenith-sky instruments of the Network for the detection of atmospheric composition change (NDACC; e.g. Roscoe et al., 1999; Vandaele et al., 2005). During CINDI, $22 \mathrm{NO}_{2}$ measuring systems were intercompared, and most of them were shown to meet the criteria for endorsement by NDACC (Roscoe et al., 2010).

\subsection{Instruments}

The present work focuses on $\mathrm{HCHO}$ measurements from MAX-DOAS instruments. Nine groups participated in this exercise, as reported in Table 1. In addition, NIWA (National institute for Water and Atmospheric Research, New Zealand) and KNMI (Koninklijk Nederlands Meteorologisch Instituut, the Netherlands) performed a few HCHO measurements during the campaign. However, these data were too sparse to include in the intercomparison.

A comprehensive description of the CINDI MAX-DOAS instruments can be found in Piters et al. (2012) and Roscoe et al. (2010), and additional references relevant for the present study are given in Table 1. All systems that operated during CINDI recorded spectra at a set of prescribed elevation angles $\left(2,4,8,15,30^{\circ}\right.$ and the zenith), and at a fixed azimuth angle of $287^{\circ}$ relative to north. A full cycle of MAXDOAS measurements was generally obtained within half an hour. For the intercomparison of HCHO, only measurements recorded at a solar zenith angle (SZA) less than $75^{\circ}$ were used in order to exclude error-prone twilight measurements that are not relevant for the present study.

As can be seen in Table 1, the characteristics of the various instruments were quite diverse, ranging from commercial mini-DOAS systems to state-of-the-art scientific grade instruments equipped with thermoelectrically cooled CCD array detectors of large dimension. Accordingly, the stability and noise levels were expected to differ considerably from one system to another, with a direct impact on corresponding $\mathrm{HCHO}$ measurements. Another important point is that some instruments were set up to record spectra in both UV and visible ranges simultaneously, while others had to alternate between these two wavelength regions. As a result, some systems (e.g. INTA and Toronto) could only measure HCHO after 30 June, at the end of the formal period of the $\mathrm{NO}_{2}$ intercomparison exercise described in Roscoe et al. (2010). Others' instruments (WSU, NASA) switched their wavelength range repeatedly over time, alternating the two types of measurements throughout the campaign. It should be noted that the MAX-DOAS instrument of the Toronto group was tested in multi-axis mode for the first time during this campaign, and only a few days of data were available.

\subsection{HCHO analysis settings}

Formaldehyde presents structured absorption bands in the UV spectral region, between 240 and $360 \mathrm{~nm}$. Because of the increased ozone absorption below $320 \mathrm{~nm}$, only the bands above $320 \mathrm{~nm}$ are generally used for the spectral retrieval of HCHO. In this region, the HCHO DSCDs are retrieved from measured spectra by applying the DOAS technique (Platt and Stutz, 2008, and references therein). The wavelength interval for fitting is generally optimized so as to (1) maximize the sensitivity to $\mathrm{HCHO}$, (2) minimize the fitting residuals and the scatter of the retrieved HCHO slant columns, and (3) minimize the interferences with other absorbers. Figure 1 displays the absorption cross sections of the trace gases that need to be considered in the $320-370 \mathrm{~nm}$ wavelength region. Based on experience and heritage from past studies on ground-based (e.g. Heckel et al., 2005; Vigouroux et al., 2009) and satellite instruments (Wittrock et al., 2006; De Smedt et al., 2008, 2009), standardized analysis settings were defined and prescribed for use in the present intercomparison exercise. These baseline settings are summarized in Table 2 . Note that all absorption cross sections were convolved to the resolution of the individual instruments using slit function information provided by each group. In the case of the $\mathrm{O}_{3}$ and $\mathrm{NO}_{2}$ cross sections, a solar $I_{0}$ correction was applied (Aliwell et al., 2002).

For the retrievals, daily reference spectra were taken from the zenith observations around 11:40UT. Figure 2 presents an example of $\mathrm{HCHO}$ fitting results obtained with the BIRAIASB (Belgian Institute for Space Aeronomy)instrument on 30 June 2009, at $4^{\circ}$ elevation angle and $43^{\circ}$ SZA. The corresponding residuals (approximately $10^{-4} \mathrm{RMS}$ ) are typical 
Table 1. Primary characteristics of the spectrometers taking part in the HCHO intercomparison campaign.

\begin{tabular}{|c|c|c|c|c|c|c|}
\hline Institute & $\begin{array}{l}\text { Measurement } \\
\text { period for } \\
\mathrm{HCHO}\end{array}$ & $\begin{array}{l}\text { FWHM } \\
(\mathrm{nm})\end{array}$ & $\begin{array}{l}\text { Sampling } \\
\text { ratio } \\
\text { (pixel/ } \\
\text { FWHM) }\end{array}$ & $\begin{array}{l}\text { Detector } \\
\text { characteristics }\end{array}$ & $\begin{array}{l}\text { Integration } \\
\text { time }\end{array}$ & Reference \\
\hline BIRA & 13 Jun-22 Jul & 0.4 & 9 & $\begin{array}{l}\text { back- } \\
\text { illuminated } \\
\mathrm{CCD}, \\
2048 \times 512 \\
\text { pixels } \\
\left(-30^{\circ} \mathrm{C}\right)\end{array}$ & $60 s$ & $\begin{array}{l}\text { Clémer et } \\
\text { al. (2010) }\end{array}$ \\
\hline $\begin{array}{l}\text { INTA, } \\
\text { Instituto } \\
\text { Nacional de } \\
\text { Tecnica } \\
\text { Aeroespacial }\end{array}$ & 7 Jul-24 Jul & 0.4 & 3.6 & $\begin{array}{l}\text { UV enhanced } \\
\text { CCD, } \\
1024 \times 256 \\
\text { pixels } \\
\left(-40^{\circ} \mathrm{C}\right)\end{array}$ & $90 \mathrm{~s}$ & $\begin{array}{l}\text { Roscoe et } \\
\text { al. }(2010)\end{array}$ \\
\hline Bremen & 8 Jun-21 Jul & 0.4 & 11.8 & $\begin{array}{l}\text { back- } \\
\text { illuminated } \\
\mathrm{CCD} \text {, } \\
2048 \times 256 \\
\text { pixels } \\
\left(-35^{\circ} \mathrm{C}\right)\end{array}$ & $40 \mathrm{~s}$ & $\begin{array}{l}\text { Wittrock } \\
\text { et al. } \\
(2004)\end{array}$ \\
\hline Heidelberg & 17 Jun-24 Jul & 0.5 & 6.5 & $\begin{array}{l}\text { back- } \\
\text { illuminated } \\
\mathrm{CCD}, \\
2048 \times 256 \\
\text { pixels } \\
\left(-30^{\circ} \mathrm{C}\right)\end{array}$ & $60 s$ & $\begin{array}{l}\text { Frieß et } \\
\text { al. }(2011)\end{array}$ \\
\hline $\begin{array}{l}\text { JAMSTEC, } \\
\text { Japan Agency for } \\
\text { Marine-Earth } \\
\text { Science and } \\
\text { Technology }\end{array}$ & 8 Jun-24 Jul & 0.7 & $\begin{array}{l}8 \\
3648 \text { pixels }\end{array}$ & uncooled CCD, & $\begin{array}{l}5 \min \\
(2011)\end{array}$ & Irie et al. \\
\hline NASA & 22 Jun-20 Jul & 0.6 & 5 & $\begin{array}{l}\text { uncooled CCD, } \\
2048 \times 14 \text { pixels }\end{array}$ & $16 \mathrm{~s}$ & $\begin{array}{l}\text { Herman et } \\
\text { al. (2009) }\end{array}$ \\
\hline $\begin{array}{l}\text { WSU, } \\
\text { Washington } \\
\text { State } \\
\text { University }\end{array}$ & 21 Jun-5 Jul & 0.83 & 8 & $\begin{array}{l}\text { back- } \\
\text { illuminated } \\
\text { CCD, } \\
2048 \times 512 \\
\text { pixels } \\
\left(-70^{\circ} \mathrm{C}\right)\end{array}$ & $\begin{array}{l}\text { Typical } \\
1.2 \mathrm{~s}\end{array}$ & $\begin{array}{l}\text { Herman et } \\
\text { al. (2009) }\end{array}$ \\
\hline Toronto & 30 Jun-4 Jul & $0.2-0.8$ & $7-12$ & $\begin{array}{l}\text { back- } \\
\text { illuminated } \\
\mathrm{CCD}, \\
2048 \times 512 \\
\text { pixels } \\
\left(-72^{\circ} \mathrm{C}\right)\end{array}$ & $\sim 2 \min$ & $\begin{array}{l}\text { Fraser et } \\
\text { al. }(2009)\end{array}$ \\
\hline Mainz & 21 Jun-10 Jul & 0.6 & 8 & $\begin{array}{l}\text { stabilised } \\
\text { CCD, } \\
2048 \text { pixels } \\
\left(4^{\circ} \mathrm{C}\right)\end{array}$ & $60 s$ & $\begin{array}{l}\text { Shaiganfar } \\
\text { et al. } \\
(2011)\end{array}$ \\
\hline
\end{tabular}


Table 2. Baseline DOAS analysis settings used for HCHO slant column retrieval during the intercomparison exercise.

\begin{tabular}{|c|c|}
\hline Parameter & Specification \\
\hline Fitting interval & $336.5-359 \mathrm{~nm}$ \\
\hline Wavelength calibration & Calibration based on reference solar atlas (Chance and Kurucz, 2010) \\
\hline \multicolumn{2}{|l|}{ Cross sections } \\
\hline $\mathrm{HCHO}$ & Meller and Moortgat (2000), $293^{\circ} \mathrm{K}$ \\
\hline $\mathrm{O}_{3}$ & Bogumil et al. (2003), 223 and $243^{\circ} \mathrm{K}, I_{0}$-corrected \\
\hline $\mathrm{NO}_{2}$ & Vandaele et al. (1996), $298^{\circ} \mathrm{K}, I_{0}$-corrected \\
\hline $\mathrm{BrO}$ & Fleischmann et al. (2004), $223^{\circ} \mathrm{K}$ \\
\hline $\mathrm{O}_{4}$ & Hermans et al. (2003) (http://spectrolab.aeronomie.be/o2.htm) \\
\hline Ring effect & Chance and Spurr (1997) \\
\hline Closure term & Polynomial of order 3 (corresponding to 4 coefficients) \\
\hline Intensity offset & Linear correction \\
\hline Wavelength adjustment & All spectra shifted and stretched against reference spectrum \\
\hline
\end{tabular}
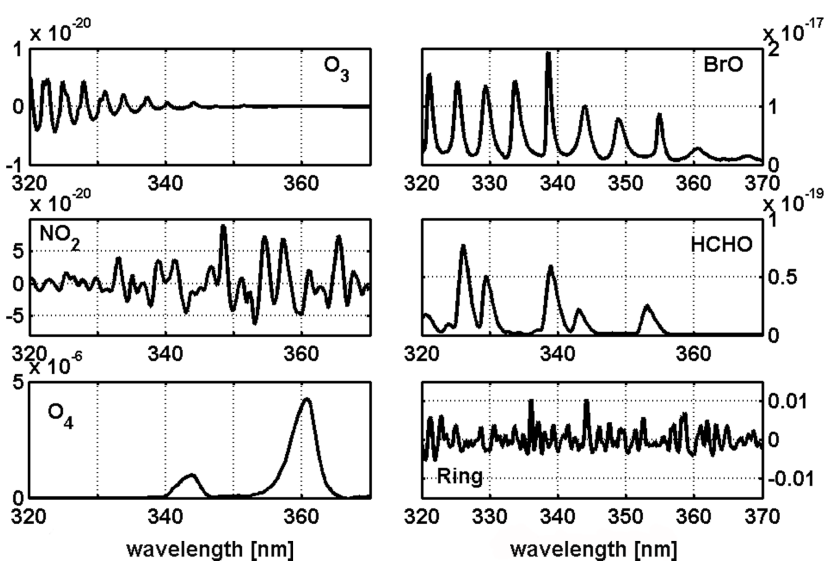

Fig. 1. Absorption cross sections of the main trace gases absorbing in the $320-370 \mathrm{~nm}$ spectral range and of the Ring effect. All absorption cross sections are expressed in $\mathrm{cm}^{2}$ molec ${ }^{-1}$, except $\mathrm{O}_{4}$ $\left(\times 10^{-40} \mathrm{~cm}^{5} \mathrm{molec}^{-2}\right)$ and have been smoothed to match the resolution of the BIRA-IASB instrument ( $0.38 \mathrm{~nm}$ FWHM).

of low-noise scientific grade instruments. Under similar conditions, residuals can be an order of magnitude larger when using compact mini-DOAS systems.

\subsection{Results}

Figure 3a shows an example of HCHO measurements obtained during CINDI. HCHO DSCDs measured by the BIRA-IASB MAX-DOAS instrument at $30^{\circ}$ elevation were converted into equivalent vertical columns (VCDs) using a simple geometrical approximation (Hönninger et al., 2004; Ma et al., 2012). The time series of HCHO VCDs covers approximately one month during summer. Comparing the retrieved columns with measurements of the ambient temperature (Fig. 3a), one can see that the HCHO variations are strongly correlated with corresponding changes in the temperature. This feature was reported by Irie et al. (2011) and is consistent with a background HCHO source, mainly due to

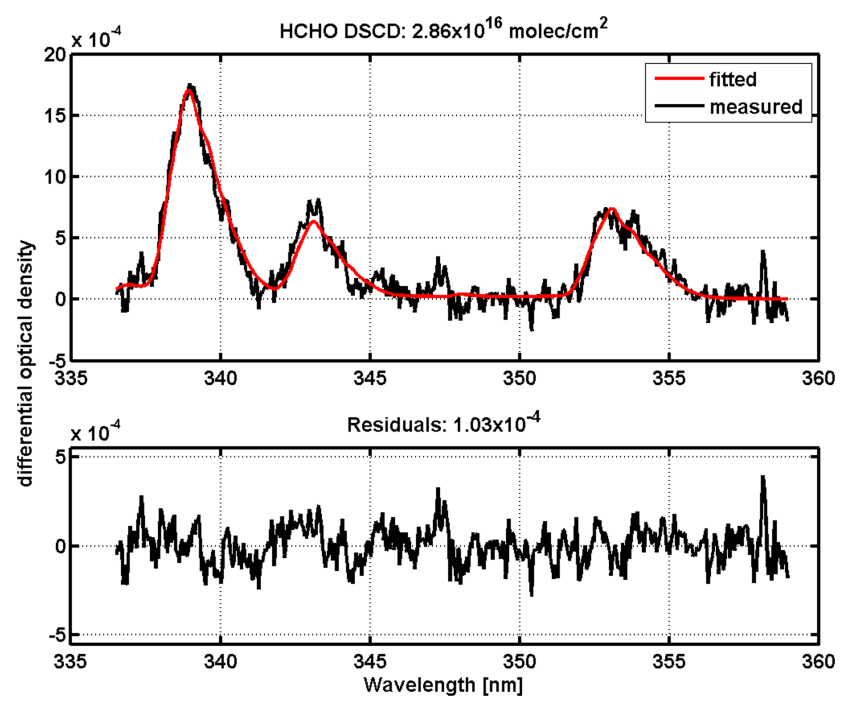

Fig. 2. Example of a HCHO slant column fit obtained with the BIRA-IASB instrument on 30 June 2009, around 14:30 UT, at $4^{\circ}$ elevation angle and $43^{\circ}$ solar zenith angle. The first panel shows the measured (black) and the fitted (red) values, and the second panel shows the residual of the DOAS fit.

the oxidation of biogenic NMVOCs. In contrast, the HCHO peak values as observed on several days in July are probably related to anthropogenic emission sources. In Fig. 3b, the complete VCD data set was binned and plotted as a function of the local time. As can be seen from the standard deviations, the natural variability of $\mathrm{HCHO}$ is large, but the diurnal variation consistently peaks in the afternoon, which is likely related to the progressive oxidation of the NMVOCs emitted during the day. 
(a)

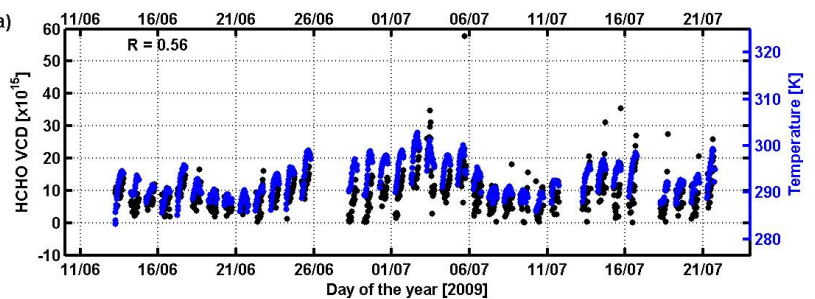

(b)

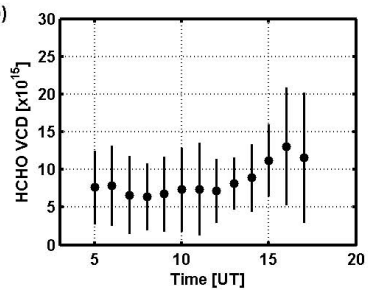

Fig. 3. $\mathrm{HCHO}$ vertical columns $\left(\operatorname{molec} \mathrm{cm}^{-2}\right)$ retrieved from BIRA-IASB MAX-DOAS measurements at $30^{\circ}$ elevation using a geometrical approximation. (a) Time series of observations performed during June and July 2009. Ambient temperature measurements are superimposed in blue. (b) Corresponding mean diurnal variation of the $\mathrm{HCHO}$ vertical column. Error bars denote the one sigma standard deviations around the mean values.
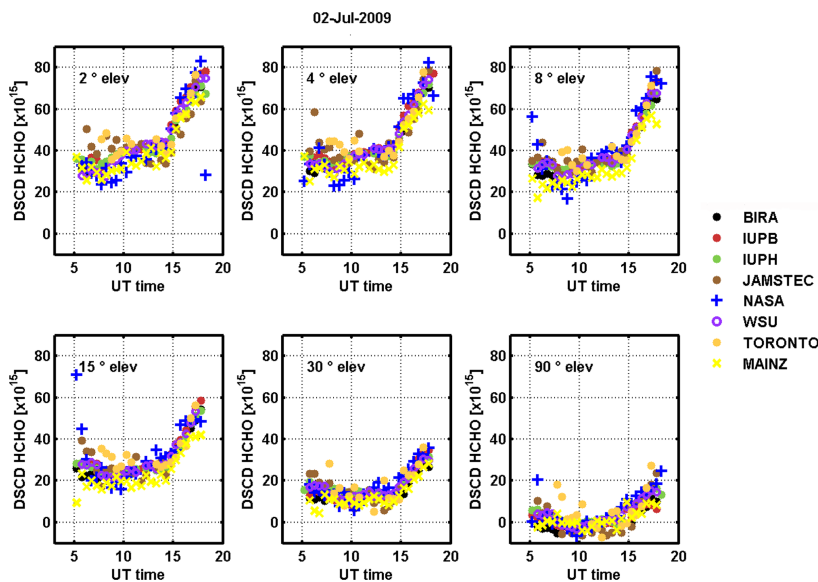

Fig. 4. Diurnal evolution of the HCHO DSCD measured on 2 July 2009 and averaged in 30-min bins, for the different instruments involved in the intercomparison. Units are molec $\mathrm{cm}^{-2}$.

\section{Slant column intercomparison results}

We follow the method introduced in Roscoe et al. (2010) for the $\mathrm{NO}_{2}$ and $\mathrm{O}_{4}$ slant column measurement intercomparison. HCHO DSCDs retrieved by each group using the baseline analysis settings defined in Table 2, are averaged over periods of $30 \mathrm{~min}$. This procedure minimizes the impact of the temporal and spatial variability of $\mathrm{HCHO}$ and of the differences in read-out noise between instruments. An example of the diurnal evolution of the resampled $\mathrm{HCHO}$ DSCDs is shown in Fig. 4 for different elevation angles and for SZA $<75^{\circ}$, on 2 July 2009 . This day was chosen because
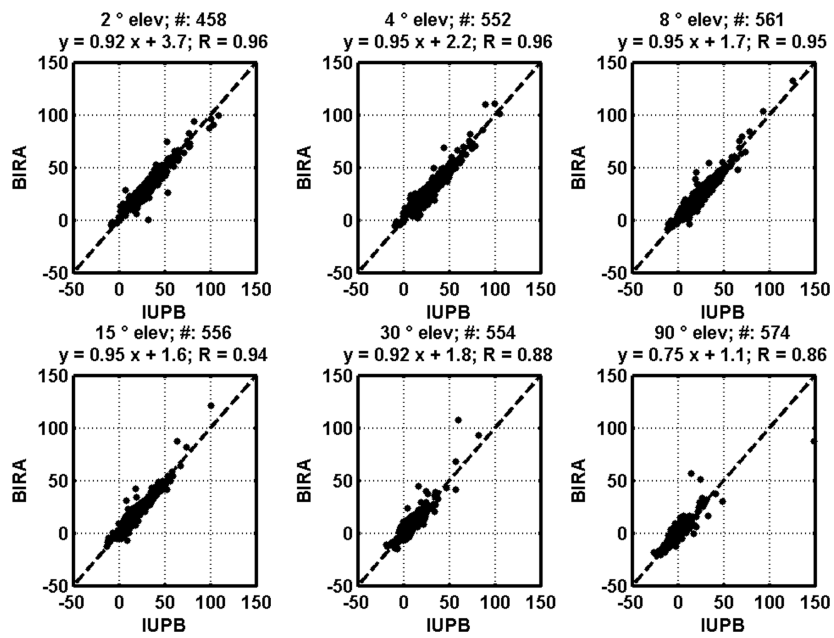

Fig. 5. Scatter plots of the HCHO DSCD $\left(10^{15}\right.$ molec $\left.^{-2}\right)$ measured by BIRA against those measured by IUP Bremen. Data from the whole campaign were averaged in 30-min bins. Statistical parameters derived from each regression plot (number of points \#, linear regression equation and correlation coefficients $R$ ) are given for each elevation above the corresponding subplots. The dashed line is the $y=x$ line.

almost all instruments were in operation and the $\mathrm{HCHO}$ concentrations had a smooth variation over time. As can be seen, the HCHO DSCDs are consistently larger at low elevation due to the enhanced light path in the near-surface $\mathrm{HCHO}$ layer; good agreement is observed between various data sets.

To proceed further, the measurements from each group were first compared to the Bremen data set, which has the most complete time series, very frequent measurements and smooth behaviour. In the second step, a reference data set was created by grouping the instruments that presented the best mutual agreement. To illustrate this procedure, Fig. 5 displays the BIRA HCHO DCSDs plotted against those of Bremen, for different elevation angles. Relevant statistical parameters (correlation coefficient, slope and intercept of the linear regression fit) are indicated. As can be seen, the scatter plots are compact, and the slopes and correlation coefficients are close to unity, confirming the good agreement between the Bremen and BIRA instruments. Statistical parameters at 30 and $90^{\circ}$ elevation are slightly smaller, due to the smaller dynamical range of the DSCDs at those elevations (see Fig. 4). Similar agreement was found with INTA, and therefore a reference data set was created by averaging data from the Bremen, BIRA and INTA instruments. The scatter plots displayed in Fig. 6 illustrate, for the $4^{\circ}$ elevation case, the results of the final comparison where data from each individual instrument are compared to the merged reference. Although the number of coincident points can differ greatly depending on instruments, the data of most of the groups agree quite well with the reference. Figure 7 presents the final results of the statistical analysis, constructed using the 

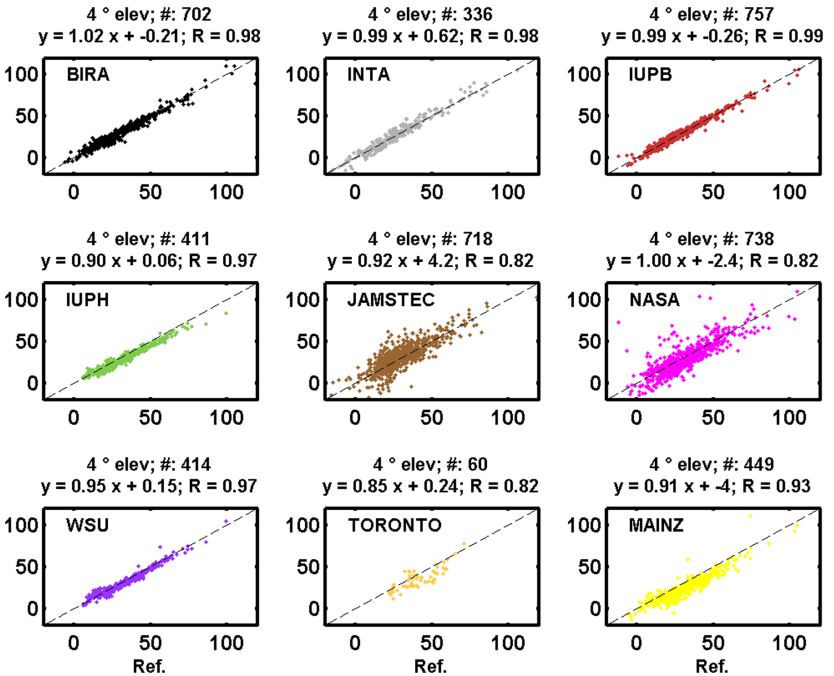

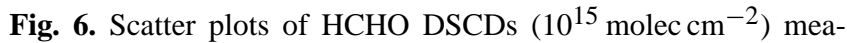
sured by each instrument compared to the campaign reference data set (see text), for the case of measurements at the $4^{\circ}$ elevation angle. Statistical parameters derived from the regressions (number of points \#, linear regression equation and correlation coefficients $R$ ) are given on top of each subplot. The dashed line is the $y=x$ line.

whole ensemble of off-axis measurements $(2,4,8,15$ and $30^{\circ}$ ). Most instruments compare relatively well with the reference for most of the elevation angles: correlation coefficients are close to unity (illustrating the compactness of the scatter plot with respect to the reference), slopes deviate by no more than $15 \%$ from the reference, and intercepts are close to zero. Note that larger relative differences against the reference are systematically obtained at $30^{\circ}$ elevations due to the lower HCHO DSCDs at this elevation angle (see Fig. 4). Also, smaller values for the correlation coefficients and larger intercept values and corresponding uncertainties are found for the JAMSTEC, NASA and Toronto data sets, which might possibly be connected to the larger noise of the corresponding instruments with respect to others (see Fig. 6). A test with an orthogonal regression (instead of linear) shows similar results.

For each instrument, the histograms of the absolute HCHO DSCDs deviations are presented in Fig. 8. Only the results at $4^{\circ}$ elevation are shown, but similar conclusions can be drawn at other elevations. All instruments, except the Toronto one, have a symmetric and quasi-Gaussian shape for the $4^{\circ}$ elevation, but large differences in the Gaussian FWHM (full width at half maximum). Largest FWHM values are found for JAMSTEC, NASA and Mainz, consistent with the noise level of those instruments. Some of the groups (IUPH, JAMSTEC, NASA, Toronto and Mainz) also display a small but significant bias compared to the reference. It should be mentioned again that the first three instruments (BIRA, INTA and Bremen) were used to construct the reference data set and thus a better agreement with the reference is expected
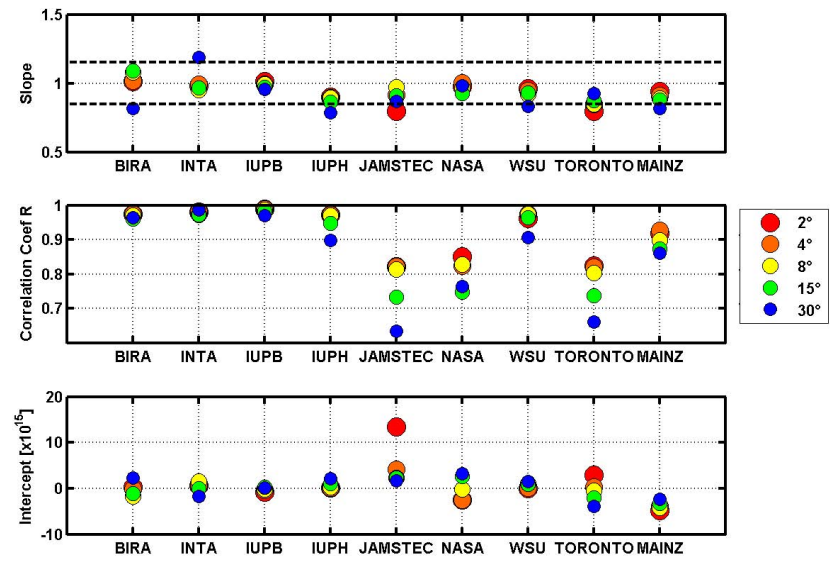

Fig. 7. Straight-line slopes, correlation coefficients and intercepts of HCHO slant columns against those of the reference, for each instrument and all off-axis elevation angles. The dotted lines in the first panel correspond to values of 1.15 and 0.85 .

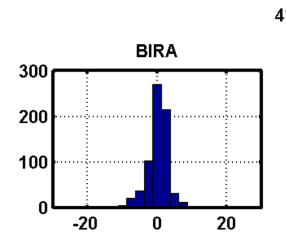

$4^{\circ}$ elevations: absolute deviations
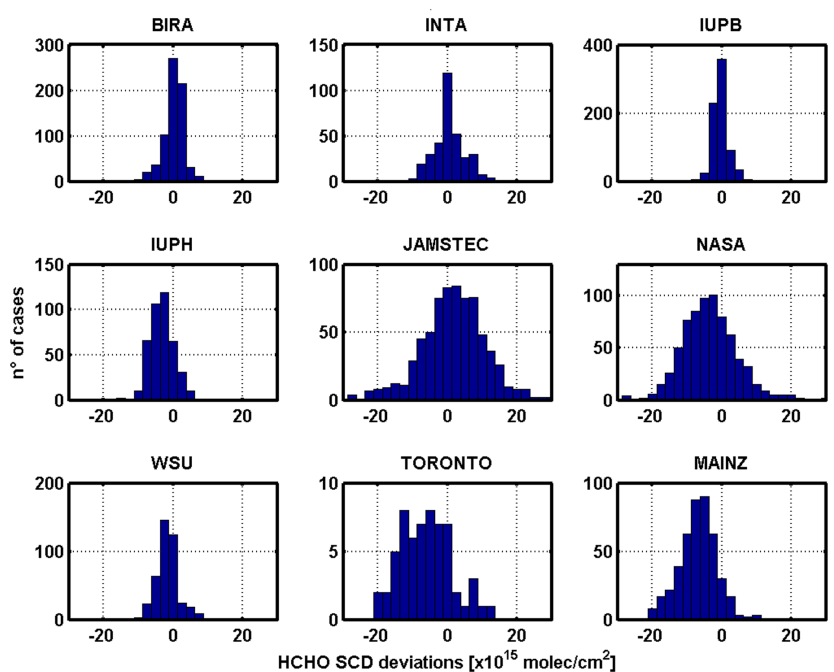

Fig. 8. Histograms of the HCHO DSCD absolute deviations $\left(10^{15}\right.$ molec $\left.\mathrm{cm}^{-2}\right)$ of each instrument's data compared to the reference set, for the case of measurements at the $4^{\circ}$ elevation angle, and for the whole campaign.

due to this choice. For the Mainz instrument, the negative bias might be related to the position of the instrument, at an altitude of $20 \mathrm{~m}$ on the Cabauw tower, where measurements probably loose sensitivity to $\mathrm{HCHO}$ present at the surface. In case of the Toronto instrument, the statistical results should be interpreted with care since there were only five days of measurements.

The HCHO intercomparison exercise presented here should be connected to the $\mathrm{NO}_{2}$ and $\mathrm{O}_{4}$ comparisons performed by Roscoe et al. (2010). They reported fitted slopes for the visible MAX-DOAS instruments within $10 \%$ of unity at almost all non-zenith elevations, with most instruments 

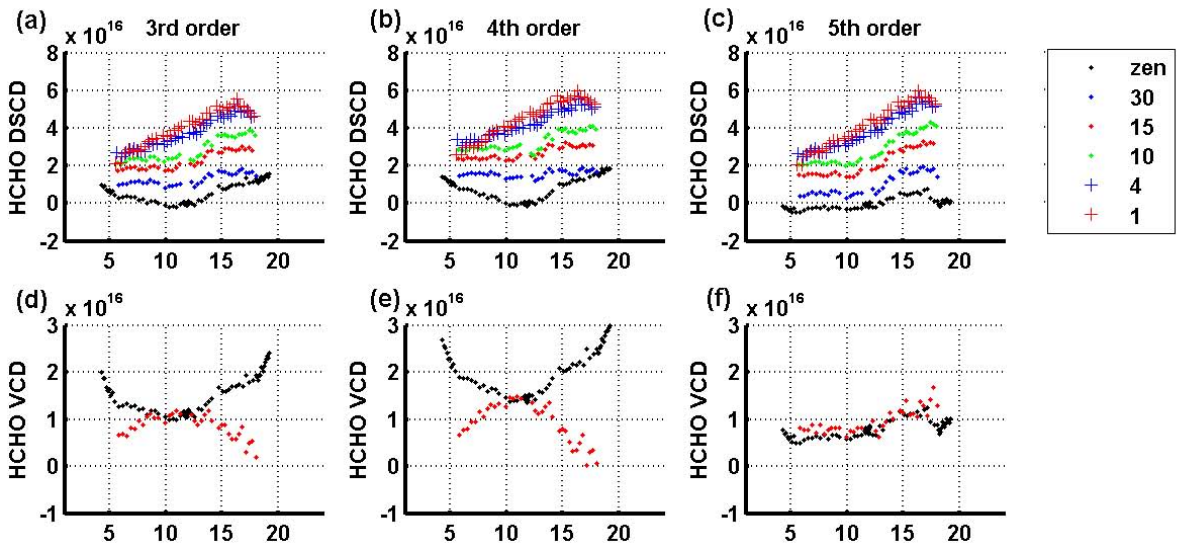

VCD from zenith sky

VCD from geom. approx.

Fig. 9. Effect of the choice of the polynomial order used in the DOAS fit. (a)-(c): Impact on the HCHO DSCDs (molec $\mathrm{cm}^{-2}$ ) for the different elevation angles; (d)-(f) impact on the corresponding HCHO VCDs (molec $\mathrm{cm}^{-2}$ ) obtained using two different methods described in the text.

within $5 \%$; similarly, values of 12 and $7 \%$, were found for the UV sensors. The $15 \%$ deviation from unity slope derived in our study for the HCHO columns in the UV are thus a good result, considering that retrieving HCHO DSCDs is more challenging than retrieving $\mathrm{NO}_{2}$, because of the smaller optical thickness of HCHO.

\section{Sensitivity study}

The intercomparison study presented in Sect. 3 has been conducted using standardized retrieval settings consistently applied by each participating group. This harmonization procedure allowed us to concentrate on instrument-specific differences, and to draw conclusions on the overall level of consistency between $\mathrm{HCHO}$ measuring systems operated during CINDI. We now concentrate on evaluating the sensitivity of $\mathrm{HCHO}$ results to possible changes in the retrieval settings using representative spectra from the BIRA instrument recorded on a clear day (4 July 2009). As will be illustrated hereafter, these sensitivity tests highlight possible optimizations in the HCHO slant column retrieval parameters and lead to the recommendation of new analysis settings. Sensitivity test results are shown both on DSCDs and on dDSCDs, i.e. the difference of the off-axis DSCDs with the zenith DSCDs of the scan (the closest in time), since this is the information used in the profile inversions.

\subsection{Degree of closure polynomial and Ring effect}

When performing a DOAS retrieval, an important free parameter is the degree of the polynomial function that is used to account for the smooth part of the attenuation spectrum. To avoid oscillations that may correlate with trace gas absorption features, the degree of this polynomial is generally restricted to values less than 5. For the baseline retrievals, a 3rd order polynomial was selected. However, during our sensitivity tests, we noticed that any changes to these polynomial settings had a strong impact on the diurnal behaviour of the HCHO DSCD, especially for high elevation angles, including zenith, as can be seen in Fig. 9a-c. This raised the following two questions: (1) Why such a dependence on the polynomial order, and (2) which one of the tested settings is the most satisfactory? In order to answer the second question, we decided to investigate the consistency of VCDs estimates as follows. In a first approximation, the HCHO VCD can be derived from measured DSCDs in two different simple ways: first, from the difference between $30^{\circ}$ elevation off-axis and zenith observations using the so-called geometrical approximation (Hönninger et al., 2004; Ma et al., 2012), and second, from direct conversion of the zenith-sky observations using appropriate AMFs. For one given observation, the AMF represents the geometrical enhancement factor that results from the geometry of the (MAX)DOAS observation and from the scattering properties of the atmosphere. AMFs are calculated using radiative transfer models accounting for multiple scattering and earth sphericity. They allow for conversion of the measured slant columns into equivalent vertical columns. For the present analysis, and considering that our test data were recorded under clear-sky aerosol-free conditions, zenith-sky HCHO AMFs were calculated using the UVspec/DISORT (DIScrete Ordinate Radiative Transfer) model (Mayer and Kylling, 2005; Hendrick et al., 2006) at the wavelength of $346 \mathrm{~nm}$ and for a typical $\mathrm{HCHO}$ profile peaking in the boundary layer. The HCHO content in the noon reference spectrum was derived using the geometrical approximation, so that both VCD evaluations (geometrical approximation and zenith-sky conversion) were constrained to agree at the time of the noon reference spectrum. The resulting time series of 


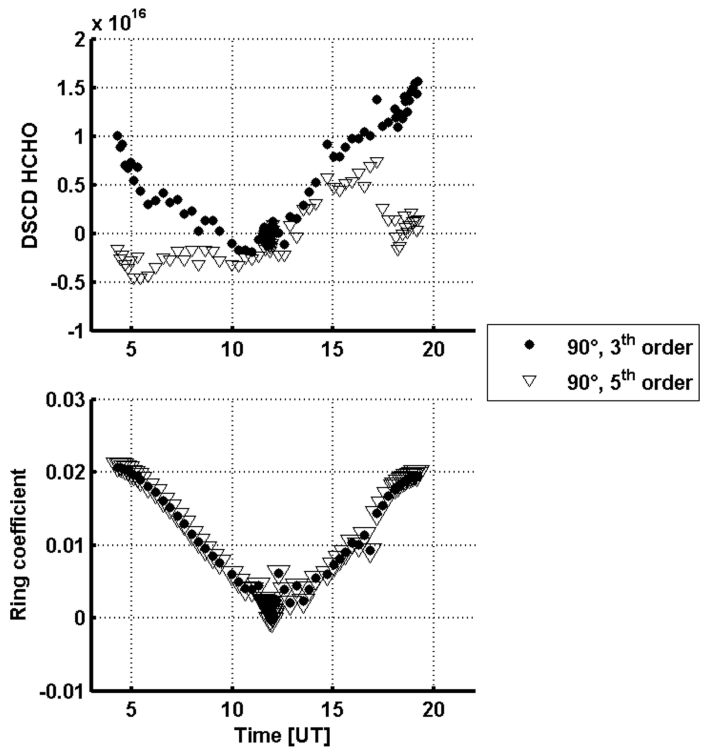

Fig. 10. Daily variation of the zenith HCHO DSCD columns (molec $\mathrm{cm}^{-2}$ ) and of the Ring coefficients for retrievals with a 3rd and 5th order polynomial. A strong correlation is observed for $\mathrm{HCHO}$ and Ring when a 3rd order polynomial is used in the DOAS retrieval.

retrieved HCHO VCDs are displayed in Fig. 9d-f for the same three polynomial settings. As can be seen, only the third case, i.e. the DOAS evaluation using a 5th order polynomial, leads to consistent retrievals of HCHO VCDs using both geometrical approximation and zenith-sky conversion.

Although these results strengthen our confidence in the corresponding HCHO DSCDs, the question remains: What is causing the observed dependence on the polynomial order? The curvature of the zenith-sky daily variation observed when using polynomials of order 3 and 4 (black dots in the first two upper plots of Fig. 9) is striking, and suggests an interference problem involving another absorber. As can be seen in Fig. 10, the Ring effect clearly displays a similar curved pattern. Additional tests showed that none of the other parameters involved in the $\mathrm{HCHO}$ retrieval produces a similar shape.

The Ring effect (Grainger and Ring, 1962) is a well-known phenomenon responsible for filling-in of the solar and telluric lines in scattered sunlight spectra (e.g. Grainger and Ring, 1962; Wagner et al., 2009 and references therein). This effect is large in comparison to the faint absorption features of $\mathrm{HCHO}$, and it can, therefore, produce interferences if not well corrected in the DOAS evaluation. To investigate further, the sensitivity of our HCHO DSCDs to uncertainties in the Ring effect, additional test analyses were performed using different sources for the Ring cross sections:

- Baseline case: cross section calculated according to Chance and Spurr (1997)
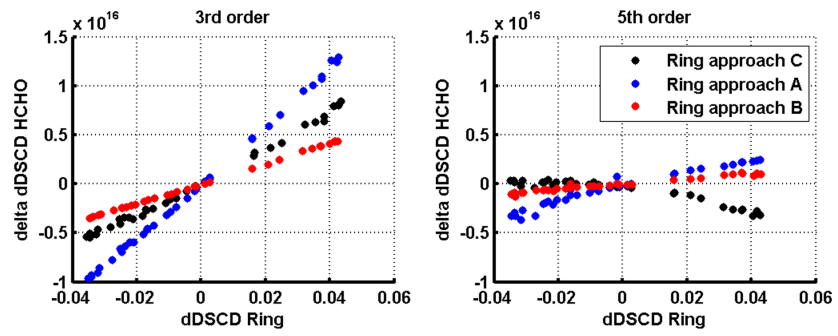

Fig. 11. Sensitivity of $\mathrm{HCHO}$ dDSCD $\left(\operatorname{molec} \mathrm{cm}^{-2}\right)$ to changes in the Ring cross section used in the DOAS fitting procedure, expressed as the difference to the baseline scenario, for data recorded on 4 July 2009. The two panels present the results for different orders of the polynomial used in the DOAS fit.

- Case A: normalised cross section generated according to Wagner et al. (2009)

- Case B: cross section derived from SCIATRAN radiative transfer calculations in a Rayleigh atmosphere (A. Richter, personal communication, 2005)

- Case C: two cross sections generated from principal component analysis of a range of SCIATRAN calculations in an ozone containing atmosphere, according to Vountas et al. (1998).

Figure 11 shows the relation between changes in HCHO DSCDs and corresponding changes in the Ring fit coefficients when using different Ring cross sections. One can see that HCHO dDSCD changes compared to the baseline (delta $\mathrm{dDSCDs}=\mathrm{dDSCD}$ (new setting) $-\mathrm{dDSCD}$ (baseline) are linearly related to changes in the Ring fit coefficients. Comparing the retrieval cases using, respectively, a 3rd and a 5th order polynomial, it is also clear that the interference between $\mathrm{HCHO}$ and the Ring effect is much stronger when a 3rd order polynomial is used (Fig. 11a). This suggests that, for our analysis conditions, the use of a 3rd order polynomial introduces a misfit that activates the correlation between Ring and $\mathrm{HCHO}$ differential absorption features. In order to further test the stability of our retrievals, with respect to this issue, a number of combinations of polynomials and Ring effect cross sections were investigated and are summarized in Fig. 12. For each case, the root mean square of the differences between HCHO VCDs retrieved using our two alternative VCD calculation methods are displayed. Overall, one can see that the sensitivity to the choice of the Ring effect cross section is smallest when using a polynomial of order 5 , for which more consistent results are obtained when changing the Ring data sets.

\section{2 $\mathrm{O}_{4}$ absorption cross section}

Another important interfering species in the HCHO fitting interval is the collisional dimer of molecular oxygen $\left(\mathrm{O}_{4}\right)$. Its absorption cross sections are still poorly characterised 


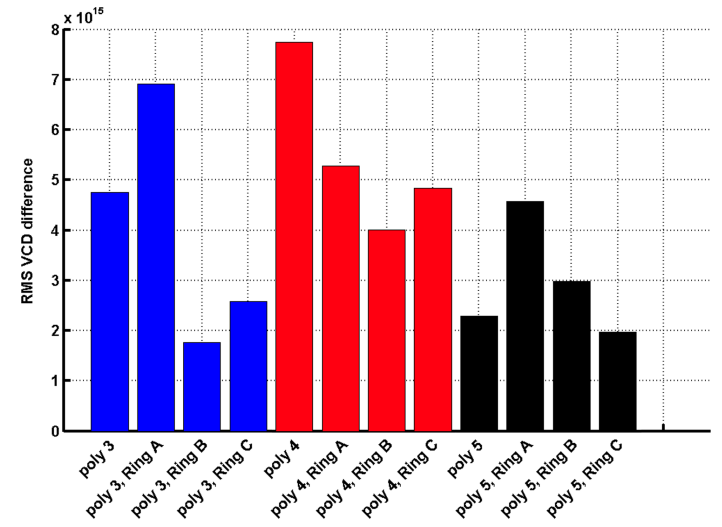

Fig. 12. Root mean square of HCHO VCD differences $\left(\right.$ molec $\mathrm{cm}^{-2}$ ) obtained using two alternative methods for the calculation of vertical columns (see text and Fig. 9). Various choices of retrieval settings are tested using polynomials of degree 3 (blue), 4 (red) and 5 (black), respectively, and different Ring effect cross sections. Optimal stability (corresponding to smallest HCHO VCD differences and larger coherence between the results with different Ring choices) is obtained for cases using a polynomial of degree 5 .

due to the difficulty of measuring them in laboratory under pressures and temperatures representative of atmospheric conditions. The Greenblatt et al. (1990) cross sections are known to suffer from wavelength registration errors and have been measured under unsuitable high pressure conditions, not present in the ambient atmosphere. Alternatively, the Hermans et al. (2003) data set provides cross sections of overall better quality, however significant uncertainties still remain, particularly in the UV region below $360 \mathrm{~nm}$. We tested both data sets, and came to the conclusion that significant interferences take place between $\mathrm{O}_{4}, \mathrm{HCHO}$ and $\mathrm{BrO}$ absorption features in the $336.5-359 \mathrm{~nm}$ interval. Figure 13 shows the HCHO and BrO DSCDs, as retrieved from MAXDOAS measurements using the Hermans et al. (2003) and the Greenblatt et al. (1990) $\mathrm{O}_{4}$ cross sections. As can be seen, the Hermans data set (our initial baseline for the intercomparison exercise) leads to larger $\mathrm{HCHO}$ columns but also to a larger spread in the BrO DSCDs retrieved at different viewing elevations, a feature that is not expected for a stratospheric absorber like BrO. In contrast, the BrO DSCDs derived using the Greenblatt $\mathrm{O}_{4}$ cross section appear to be more consistent. Similarly to the case of the polynomial discussed before, this suggests that a misfit to the $\mathrm{O}_{4}$ absorption (larger in this case using the Hermans et al, 2003, data set) activates a correlation between $\mathrm{HCHO}$ and $\mathrm{BrO}$ DSCDs. We will revisit the origin of these correlations in the next section. The linear relationship between $\mathrm{HCHO}, \mathrm{BrO}$ and $\mathrm{O}_{4}$ DSCDs changes when switching from the Hermans et al. (2003) to the Greenblatt et al. cross sections, as is clearly apparent from Fig. 14. Based on these considerations, we conclude that the Greenblatt et al. (1990) $\mathrm{O}_{4}$ cross section, so far, remains the better choice for HCHO retrieval in the $336.5-359 \mathrm{~nm}$ region.

\subsection{DOAS fitting interval}

As already mentioned, the baseline $\mathrm{HCHO}$ fitting interval selected for the present study extends from 336.5 to $359 \mathrm{~nm}$. This wavelength region, which includes three strong absorption bands of $\mathrm{HCHO}$, has generally been recommended for HCHO DSCD retrievals. However, the absorption structures of $\mathrm{HCHO}$ and $\mathrm{BrO}$ are to some extent correlated in this wavelength interval, which has been identified as an issue for satellite $\mathrm{BrO}$ retrievals (Theys et al., 2011). Figure 15b graphically displays the correlation matrix of the different absorption cross sections used in the $\mathrm{HCHO}$ fit. As can be seen, $\mathrm{HCHO}$ and $\mathrm{BrO}$ present the largest coefficient of correlation (around 0.55 ), which can be easily explained by the similarities of their differential absorption cross sections (see Fig. 15a). In comparison, other species are less correlated. However, the coefficient of correlations between $\mathrm{HCHO}$ and $\mathrm{O}_{3}$ and for other combinations involving $\mathrm{O}_{3}, \mathrm{O}_{4}, \mathrm{BrO}, \mathrm{NO}_{2}$ and Ring are not negligible. Such correlations may be expected to be dependent on the wavelength interval considered for the analysis. Therefore, in an attempt to identify the settings that would minimize the correlation matrix, calculations were performed for a range of fitting intervals starting between 332 and $338 \mathrm{~nm}$ and ending between 352 and $360 \mathrm{~nm}$, in steps of $0.25 \mathrm{~nm}$, in a similar way than what was done in Vogel et al. (2012). For each case, the root mean square of the non-diagonal elements of the correlation matrix was reported in Fig. 15c. Smaller correlations are clearly found for fitting intervals starting at short wavelengths. From visual inspection of Fig. 15c, one can conclude that the 333 $358 \mathrm{~nm}$ wavelength range presents a local minimum of correlation, likely because of the addition of a $\mathrm{BrO}$ band at $334 \mathrm{~nm}$ in a region free of $\mathrm{HCHO}$ absorption. Note that this wavelength interval is similar to the one selected in Theys et al. (2011) for their satellite retrievals of BrO.

To further explore the potential of this extended fitting interval on our HCHO MAX-DOAS retrievals, additional sensitivity tests were performed. Results again show large instabilities with respect to the Ring effect interference. This is illustrated in Fig. 16a-c, where the HCHO DSCD retrieved in the 333-358 nm interval with a 5th order polynomial and $\mathrm{O}_{4}$ Greenblatt et al. (1990) data set, is displayed for different elevation angles and for different choices of the Ring cross sections. As can be seen, the diurnal behaviour of the retrieved HCHO DSCDs has a large dependence on the source of the Ring cross section used in the DOAS fit, and the corresponding HCHO VCDs calculated using the two methods introduced in section Sect. 4.1 are generally inconsistent. These results suggest that the extended fitting interval that minimizes the $\mathrm{BrO}-\mathrm{HCHO}$ interference is also more sensitive to Ring effect misfits. Therefore, any attempt to use this interval should be made with great care. 

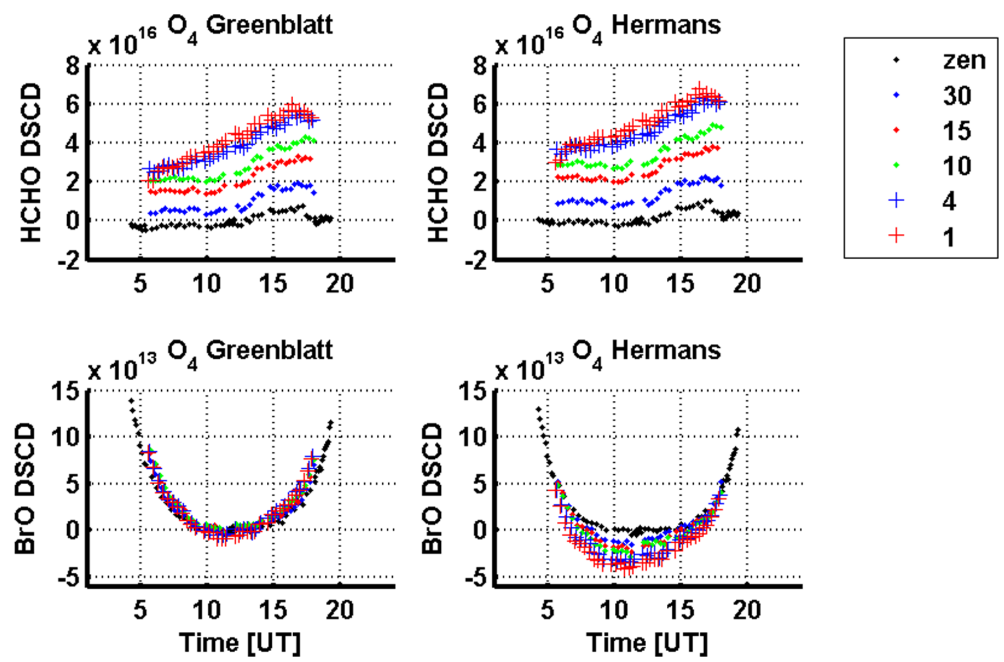

Fig. 13. Effect of the choice of the $\mathrm{O}_{4}$ cross section used in the DOAS fit, on HCHO and BrO DSCD columns (molec $\mathrm{cm}^{-2}$ ). Results (a) and (c) are obtained with the Greenblatt et al. (1990) cross sections while (b) and (d) are obtained using the Hermans et al. (2003) cross sections.

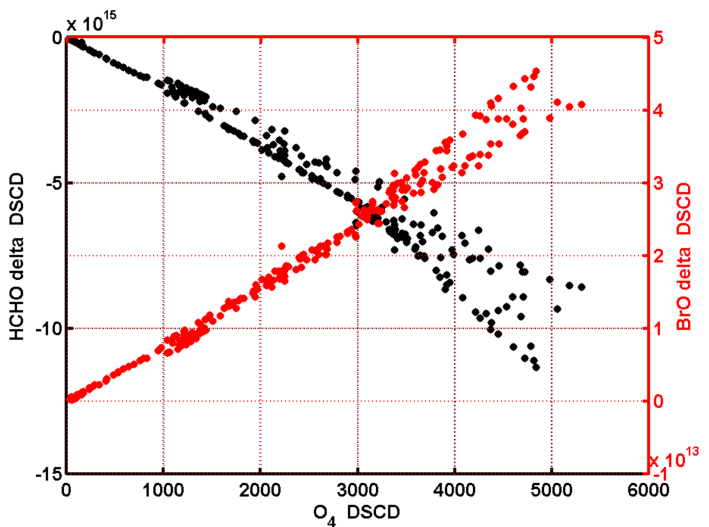

Fig. 14. Change in retrieved $\mathrm{HCHO}$ (black) and BrO DSCDs (red) (delta dDSCDs = dDSCD (new setting) $-\mathrm{dDSCD}$ (baseline); in molec $\mathrm{cm}^{-2}$ ) when exchanging the Hermans et al. (2003) $\mathrm{O}_{4}$ absorption cross section for the Greenblatt et al. (1990) data set, expressed as a function of the $\mathrm{O}_{4}$ DSCD values (in $10^{40} \mathrm{molec}^{2} \mathrm{~cm}^{-5}$ ).

\subsection{Recommended analysis settings}

The sensitivity studies, performed on BIRA data of 4 July 2009, revealed several possible optimisations of the HCHO DOAS retrieval, in order to minimise interferences and misfits related to polynomial order, Ring effect and $\mathrm{O}_{4}$ and $\mathrm{BrO}$ absorption cross sections. Compared to the settings used during the intercomparison exercise and presented in Table 2, the use of a 5th degree polynomial and the wavelength corrected $\mathrm{O}_{4}$ Greenblatt et al. (1990) cross section is recommended. Applied in the 336.5-359 nm wavelength interval, these changes reduce instabilities related to the Ring effect and lead to more consistent BrO DSCDs. Sensitivity tests involving other parameters revealed a comparatively
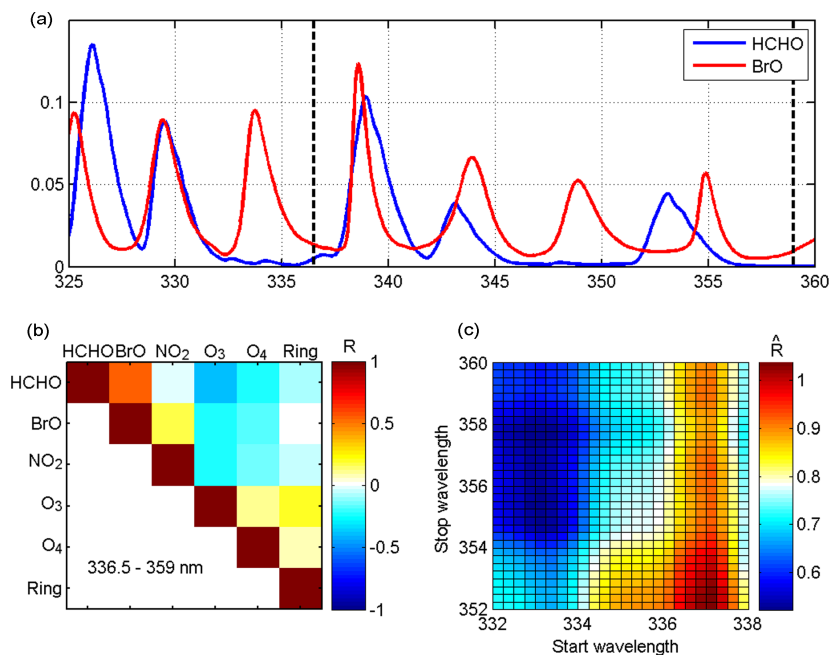

Fig. 15. (a) $\mathrm{HCHO}$ and $\mathrm{BrO}$ absorption cross sections in the 325$360 \mathrm{~nm}$ wavelength range convolved at the resolution of the BIRA instrument $(0.38 \mathrm{~nm}$ FWHM) and normalized in arbitrary units. (b) Correlation matrix of the absorption cross sections used for HCHO DOAS retrievals in the $336.5-359 \mathrm{~nm}$ interval. (c) Overall correlation (expressed as the root mean square of the non-diagonal elements of the correlation matrix) for different wavelength intervals in the $332-360 \mathrm{~nm}$ wavelength range.

small impact on the HCHO evaluations. This is further discussed in the next section, where the systematic and random uncertainties on HCHO DSCD retrievals are reviewed in more detail. 

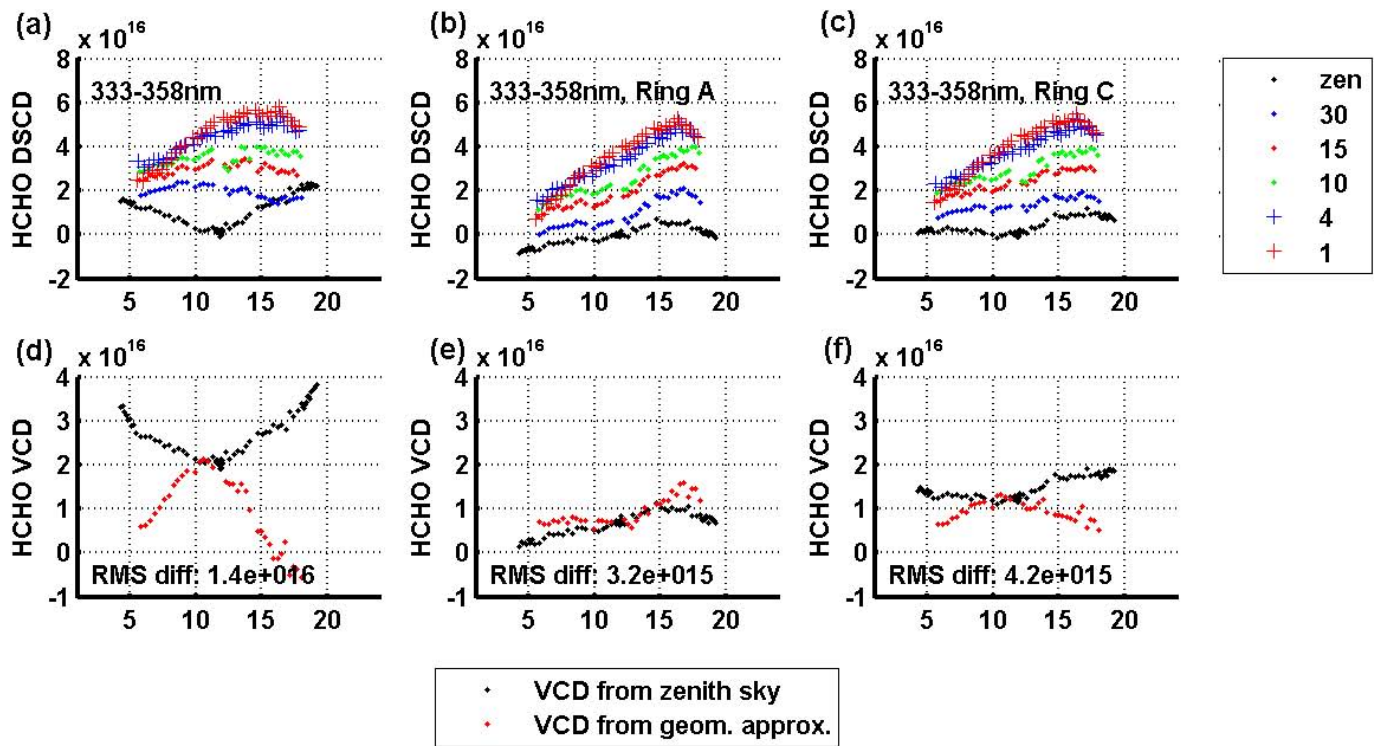

Fig. 16. Same as Fig. 9, but for an analysis in the 333-358 nm wavelength region, with a 5th order polynomial and the $\mathrm{O}_{4} \mathrm{Greenblatt} \mathrm{et}$ al. (1990) data set, and for different choices of the Ring cross sections. Both DSCDs and VCDs are expressed in $\mathrm{molec}^{-2}$.

\section{Error budget}

The total uncertainties on the HCHO DSCDs retrieval can be divided into two categories: (1) the random errors mostly caused by measurement noise, and (2) errors affecting the slant columns in a systematic way.

\subsection{Random uncertainties}

Random errors in DOAS observations are primarily related to the measurement noise which, for silicon array detectors, is generally limited by the photon shot noise. Assuming that the errors of the individual detector pixels are uncorrelated and that the DOAS fit residuals are dominated by instrumental noise, the random contribution to the DSCD error can be derived from the DOAS least-squares fit error propagation (e.g. Stutz and Platt, 1996). Random errors are then adequately represented by the slant column fit errors. Any deviation with respect to these assumptions generally results in an overestimation of the random error, so one can consider to a first approximation that the DOAS DSCD error constitutes an upper limit of the true random error. For the instruments involved in this exercise, slant column errors varying between $\sim 1 \times 10^{15} \mathrm{molec} \mathrm{cm}^{-2}$ and $\sim 2 \times 10^{16}$ molec cm $^{-2}$ were reported by the different groups as illustrated in Fig. 17a for 4 July 2009 at SZA less than $75^{\circ}$. As expected, scientific grade instruments (BIRA, Bremen, IUPH, WSU) display small errors of the order of $1 \times 10^{15} \mathrm{molec} \mathrm{cm}^{-2}$, while mini-DOAS types of instruments (e.g. Mainz) are significantly noisier, typical errors reaching $5 \times 10^{15}$ molec cm$^{-2}$ or more. In order to better compare the actual performances of the different instruments, the DSCD errors were further
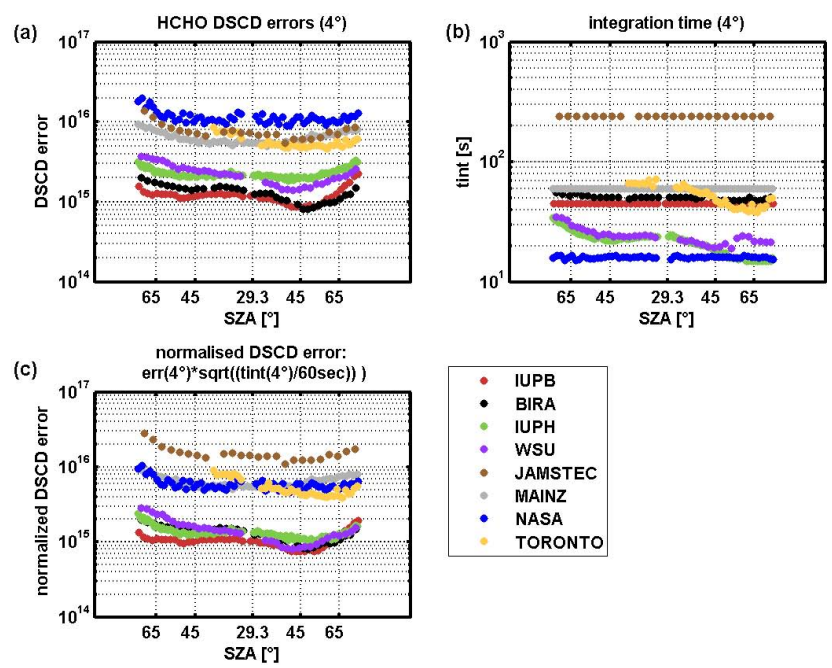

Fig. 17. Comparison of HCHO DSCD errors $\left(\operatorname{molec} \mathrm{cm}^{-2}\right)$ retrieved by each participating group for the case of $4^{\circ}$ elevation, based on measurements from 4 July 2009. (a) DSCD errors from DOAS evaluations, (b) corresponding integration times, (c) DSCD errors normalized by their integration exposure times.

normalised to a common integration time of 1 min. As can be seen in Fig. 17c, this largely improves the consistency between the scientific-grade instruments, which all display similar noise levels. The NASA and Mainz instruments, which use small and uncooled or less cooled detectors (see Table 1) have larger errors as is to be expected. More surprisingly, the Toronto data appear to display a similar level of noise, despite the fact that this instrument was using a large 2-D cooled array detector. This is likely related to a mechanical 
slit problem having occurred during the campaign that reduced the signal to $25 \%$ of normal values. Also, temperature instabilities have led to systematic features in the residuals that affected DSCD error estimates reported by this group. During part of the campaign, the Bremen instrument had a high frequency structure in the residuals which could be accounted for by using an empirical correction. The problem could not be reproduced in the laboratory after the campaign and appears not to have impacted the $\mathrm{NO}_{2}$ and $\mathrm{HCHO}$ retrievals. The INTA instrument (not on Fig. 17 because it was not measuring on 4 July) is showing similar level of noise. When normalised to the same integration time as the other instruments, JAMSTEC appears to have been the noisiest system operated during the campaign.

\subsection{Systematic uncertainties}

Several important sources of systematic uncertainty have already been discussed in depth as part of our sensitivity analysis, which led us to propose optimised $\mathrm{HCHO}$ retrieval settings that minimise interference effects involving the polynomial closure term, Ring effect, $\mathrm{O}_{4}, \mathrm{BrO}$ and $\mathrm{HCHO}$ cross sections. In this section, additional uncertainties are treated with the aim of providing a comprehensive error budget for dDSCDs, as these are the main input parameters for retrieving profile information. This includes the impact of systematic uncertainties in absorption cross sections as well as errors due to calibration uncertainties, in particular the slit function and the wavelength calibration, which are key parameters for DOAS retrievals.

\subsubsection{Absorption cross sections}

\section{HCHO}

Two sources of HCHO absorption cross sections have been used in the literature, the Cantrell et al. (1990) spectrum and the Meller and Moortgat (2000) data set. The latter was adopted for our baseline. HITRAN recommends the use of the Cantrell data set, rescaled to correct for its systematically low bias (Chance and Orphal, 2011). In the 336.5$359 \mathrm{~nm}$ interval and at the resolution of the BIRA spectrometer, the cross sections differ by approximately $9 \%$, a difference which was found to propagate directly to the slant column retrievals. The temperature dependence of the HCHO absorption cross section is small, of the order of $0.05 \% \mathrm{~K}^{-1}$ (De Smedt, 2011) and its effect was neglected here since the Meller and Moortgat cross section was measured at $293^{\circ} \mathrm{K}$, a temperature representative of ambient conditions during CINDI.

\section{BrO}

Two main sources of $\mathrm{BrO}$ cross sections can be found in the literature: Wilmouth et al. (1999) and Fleischmann et al. (2004). These data sets are highly consistent in shape and their use was found to result in very small differences in the HCHO dDSCD, of the order of a few $10^{14}$ molec $\mathrm{cm}^{-2}$. For a median $\mathrm{dDSCD}$ of $3.8 \times 10^{16}$ molec $\mathrm{cm}^{-2}$ at $4^{\circ}$ elevation, the difference is therefore less than $2 \%$.

\section{Ozone}

The baseline intercomparison settings used the Bogumil et al. (2003) ozone absorption cross sections. We have tested the impact of using the alternative data set from Brion, Daumont and Malicet (BDM, Daumont et al., 1992; Malicet et al., 1995). The resulting HCHO dDSCDs were found to be larger by approximately $5 \times 10^{15}$ molec $\mathrm{cm}^{-2}$. For a median dDSCD of $3.8 \times 10^{16}$ molec cm$^{-2}$ at $4^{\circ}$ elevation, the difference is on the order of $13 \%$ during the day.

\section{Ring effect}

Although the cross-talk between $\mathrm{HCHO}$ and the Ring effect has been strongly reduced using the new baseline settings defined in Sect. 4 (see Fig. 10), some level of correlation persists between these parameters. As a result, $\mathrm{HCHO}$ uncertainties are expected to be linked to the strength of the Ring effect, which itself is a function of the geometry, SZA and aerosol content (Wagner et al., 2009). When considering the Ring cross section that leads to the larger differences, (in most cases approach A), typical uncertainties on the HCHO DSCD reaches up to 5 to $12 \%$.

\section{$\mathrm{NO}_{2}$}

The baseline intercomparison settings used the Vandaele et al. (1996) $\mathrm{NO}_{2}$ absorption cross sections at $298^{\circ} \mathrm{K}$. Switching to the alternative data set of Burrows et al. (1998) HCHO DSCDs are found to vary by 2 to $5 \%$, depending on the $\mathrm{NO}_{2}$ content.

$\mathbf{O}_{4}$

The choice of the $\mathrm{O}_{4}$ cross section has been already largely discussed in Sect. 4.2. Adopting the Greenblatt et al. (1990) data set, which minimises inconsistencies in the $\mathrm{BrO}$ slant columns, we further neglect residual errors related to $\mathrm{O}_{4}$. It should be noted that in this study, a wavelength axis corrected version of the Greenblatt et al. (1990) data set has been used (see e.g. Wagner et al., 2002), with a shift of $-0.2 \mathrm{~nm}$.

\subsubsection{Instrumental slit function and wavelength calibration}

Uncertainties in key instrumental calibration parameters may also be important. For example, imperfect characterisation of the slit function can lead to errors in the HCHO retrieval due to inappropriate convolution of the laboratory absorption cross sections. This effect was tested by changing slightly the width of the measured slit function of the BIRA instrument 
(changes of $\pm 0.04 \mathrm{~nm}$ around the measured value of $0.38 \mathrm{~nm}$ Gaussian FWHM). This led, for example, to changes in the $\mathrm{HCHO}$ dDSCD at $4^{\circ}$ elevation of $1 \times 10^{15} \mathrm{molec}^{-2}$, corresponding to relative differences of around $2 \%$. In addition, small perturbations to the wavelength registration of the spectra were introduced in order to test the sensitivity of the retrievals to known uncertainties in the wavelength calibration procedure. Results indicate changes of the order of $2 \times 10^{15} \mathrm{molec} \mathrm{cm}^{-2}$ for the $4^{\circ} \mathrm{dDSCD}$ (around $5 \%$ ) for shifts of $0.02 \mathrm{~nm}$. We therefore conclude that uncertainties in the instrumental slit function and the wavelength calibration have a minor impact.

Another potentially important source of error already identified in the CINDI $\mathrm{NO}_{2}$ study by Roscoe et al. (2010) is the accuracy of the pointing direction. This issue was addressed early in the campaign, before the HCHO intercomparison was started, checking the alignment of each instrument and minimizing the pointing errors (Roscoe et al., 2010). Moreover, since this error source does not affect directly the DOAS evaluations, but more the determination of the corresponding air mass factors, we do not treat it explicitly here. It should, of course, be considered for a full error analysis of vertical column and/or profile concentration retrieval of HCHO.

\subsection{Overall error budget}

Based on the results discussed above, an overall assessment of the total uncertainties on HCHO dDSCDs has been generated, including the main contributions of systematic and random errors, and is shown in Fig. 18. The figure summarises the main results from the sensitivity study for an elevation angle of $4^{\circ}$ with a typical dDSCD of $3.8 \times 10^{16}$ molec $\mathrm{cm}^{-2}$, which is the median value during 4 July 2009. For most cases, the retrieved HCHO dDSCDs fall within $15 \%$ of the values obtained with the optimised settings defined in Sect. 4 . Assuming that the different effects are sufficiently uncorrelated with each other, we can sum all deviations in quadrature to obtain an estimate of the overall systematic uncertainty, which is represented by the black line in Fig. 18. On this basis, we estimate the total systematic uncertainties on $\mathrm{HCHO}$ dDSCDs to be of approximately $20 \%$ for measurements at $4^{\circ}$ elevation, with a weak dependence on the SZA. Since some of the effects considered in our study are likely to be partly correlated, these values could be considered as upper limits, however, despite our efforts to include the most important sources of uncertainties in our sensitivity analysis, the need for possible additional terms cannot be excluded apriori. Moreover, the results presented here are based on a single day of measurements and are influenced by the atmospheric conditions on that day. Therefore, arguably, the uncertainties reported here are to be interpreted as realistic conservative values.

In Fig. 18, the random error is estimated for a typical integration time of one minute. We distinguish between two

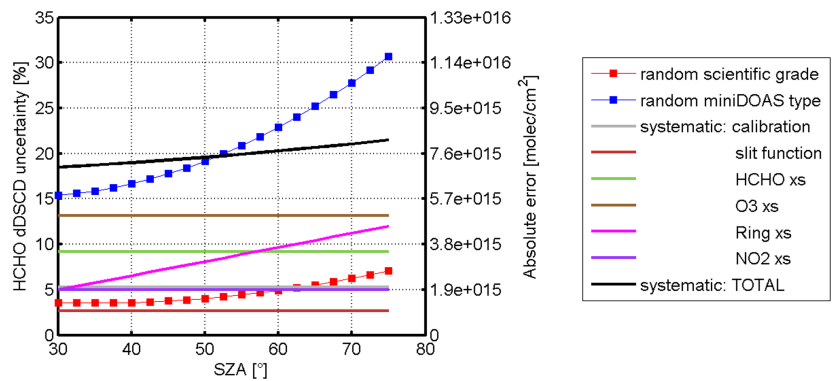

Fig. 18. Summary assessment of the error budget on HCHO dDSCD at $4^{\circ}$ elevation, as a function of the SZA. Random uncertainties are typical of low-noise scientific grade instruments (red dots) and of mini-DOAS types of instruments (blue dots) for a typical integration exposure time of $1 \mathrm{~min}$.

typical cases corresponding to low-noise scientific grade instruments and to mini-DOAS types of instruments, respectively. As can be seen for scientific grade instruments, the total errors on individual measurements are largely dominated by the systematic part. For mini-DOAS instruments, both random and systematic uncertainties contribute similarly. As already mentioned, the random uncertainty can be reduced by means of longer integration time and, for less sensitive mini-DOAS instruments, a trade-off between error and temporal resolution has to be made.

\section{Conclusions}

HCHO differential slant columns were retrieved from nine different MAX-DOAS instruments jointly operated during the CINDI campaign in Cabauw, the Netherlands, from June to July 2009. This exercise complements the formal semiblind $\mathrm{NO}_{2}$ and $\mathrm{O}_{4}$ slant column intercomparison performed during the same campaign (Roscoe et al., 2010). To reduce the impact of uncertainties on retrieval parameters, common DOAS analysis settings were used by the different groups. In addition, 30-min averages were taken to reduce differences in temporal sampling. The HCHO differential slant columns retrieved by the different groups generally agree within $15 \%$, which is very satisfactory and almost as good as the agreement obtained for the $\mathrm{NO}_{2}$ and $\mathrm{O}_{4}$ intercomparison (Roscoe et al., 2010). This exercise shows that a large variety of MAX-DOAS instruments of different grades and sensitivities can consistently measure $\mathrm{HCHO}$ columns within acceptable errors. However, while scientific grade instruments clearly demonstrate their ability to provide low-noise measurements at high temporal resolution (less than $30 \mathrm{~min}$ ), less sensitive mini-DOAS instruments display significantly larger noise, which probably compromises their ability to deliver vertical profile information at the same temporal resolution.

A number of sensitivity tests was performed to investigate the sensitivity of HCHO retrievals to changes in DOAS analysis settings and input data sets. The study highlights the 
role of cross-correlation effects involving Ring effect, $\mathrm{O}_{4}$, $\mathrm{BrO}$ and $\mathrm{HCHO}$ absorption cross sections and the order of the DOAS closure polynomial. Optimised retrieval settings are proposed with the aim to minimise correlation effects. Furthermore, systematic and random uncertainties are estimated for typical observation conditions. The largest systematic errors are found to be related to the Ring effect and to the uncertainties in $\mathrm{HCHO}$ and $\mathrm{O}_{3}$ absorption cross sections. We conclude that the overall systematic uncertainty on the HCHO DSCD retrievals is of the order of $20 \%$ with a weak dependence on the solar zenith angle. Total errors are dominated by systematic effects for the scientific grade instruments, while both systematic and random uncertainties contribute at the same level for mini-DOAS-like instruments.

Finally, it must be pointed out that issues already identified during the semi-blind $\mathrm{NO}_{2}$ and $\mathrm{O}_{4}$ intercomparison (Roscoe et al., 2010) remain largely valid for the present study on HCHO. In particular, the accuracy of slant column measurements crucially depends (especially for low elevation angles) on the accuracy of the pointing direction, which should therefore be checked on a regular basis. Also, the temporal variability in tropospheric signals can be large, even if this variability is expected to be less important for $\mathrm{HCHO}$ than for $\mathrm{NO}_{2}$. For future MAX-DOAS intercomparisons, a better synchronisation of the measurements should be considered to minimise the scatter possibly introduced by differences in measurement time.

Acknowledgements. The authors wish to thank the KNMI staff at Cabauw for their technical assistance and for the infrastructure that was offered during the campaign. The CINDI Campaign was funded by ESA and EU, through the CEOS and ACCENT-AT2 projects, respectively. We further acknowledge the support of the EU via the GEOMON Integrated Project and via the FP 7 project NORS (284421), and of the Belgian Science Policy via the AGACC-II project. We also thank Isabelle De Smedt and Nicolas Theys for helpful discussions during the preparation of this manuscript. The participation of the Toronto team was supported by the Canadian Foundation for Climate and Atmospheric Science and the Centre for Global Change Science at the University of Toronto; the instrument was funded by the Natural Sciences and Engineering Research Council and the Canadian Foundation for Innovation, and is usually operated at the Polar Environment Atmospheric Research Laboratory (PEARL) by the Canadian Network for the Detection of Atmospheric Change (CANDAC).

Edited by: J. Stutz

\section{References}

Aliwell, S. R., Van Roozendael, M., Johnston, P. V., Richter, A., Wagner, T., Arlander, D. W., Burrows, J. P., Fish, D. J., Jones, R. L., Tørnkvist, K. K., Lambert, J.-C., Pfeilsticker, K., and Pundt, I.: Analysis for BrO in zenith-sky spectra: An intercomparison exercise for analysis improvement, J. Geophys. Res., 107, D140, doi:10.1029/2001JD000329, 2002.

Bobrowski, N., Hönninger, G., Galle, B., and Platt, U.: Detection of bromine monoxide in a volcanic plume, Nature, 423, 273-276, doi:10.1038/nature01625, 2003.

Bogumil, K., Orphal, J., Homann, T., Voigt, S., Spietz, P., Fleischmann, O. C., Vogel, A., Hartmann, M., Bovensmann, H., Frerik, J., and Burrows, J. P.: Measurements of molecular absorption spectra with the SCIAMACHY Pre-Flight Model: Instrument characterization and reference spectra for atmospheric remote sensing in the $230-2380 \mathrm{~nm}$ region, J. Photochem. Photobiol. A, 157, 167-184, 2003.

Brinksma, E. J., Pinardi, G., Volten, H., Braak, R., Richter, A., Schoenhardt, A., Van Roozendael, M., Fayt, C., Hermans, C., Dirksen, R. J., Vlemmix, T., Berkhout, A. J. C., Swart, D. P. J., Oetjes, H., Wittrock, F., Wagner, T., Ibrahim, O., de Leeuw, G., Moerman, M., Curier, R. L., Celarier, E. A., Cede, A., Knap, W. H., Veefkind, J. P., Eskes, H. J., Allaart, M., Rothe, R., Piters, A. J. M., and Levelt, P. F.: The 2005 and 2006 DANDELIONS $\mathrm{NO}_{2}$ and aerosol intercomparison campaigns, J. Geophys. Res., 113, D16S46, doi:10.1029/2007JD008988, 2008.

Burrows, J. P., Dehn, A., Deters, B., Himmelmann, S., Richter, A., Voigt, S., and Orphal, J.: Atmospheric remote-sensing reference data from GOME: Part 1. Temperature-dependent absorption cross-sections of NO2 in the 231-794 nm range, J. Quant. Spectrosc. Ra., 60, 1025-1031, 1998.

Cantrell, C. A., Davidson, J. A., McDaniel, A. H., Shetter, R. E., and Calvert, J. G.: Temperature-dependent formaldehyde cross sections in the near ultraviolet spectra region, J. Phys. Chem., 94, 3902-3908, 1990.

Chance, K. and Kurucz, R. L.: An improved high-resolution solar reference spectrum for Earth's atmosphere measurements in the ultraviolet, visible, and near infrared, http://www.cfa.harvard. edu/atmosphere (last access: July 2011), 2010.

Chance, K. and Orphal, J.: Revised ultraviolet absorption cross sections of $\mathrm{H}_{2} \mathrm{CO}$ for the HITRAN database, J. Quant. Spectrosc. Ra., 112, 1509-1510, doi:10.1016/j.jqsrt.2011.02.002, 2011.

Chance, K., Palmer, P. I., Spurr, R. J., Martin, R. V., Kurosu, T. P., and Jacob, D. J.: Satellite observations of formaldehyde over North America from GOME, Geophys. Res. Lett., 27, 34613464, 2000.

Chance, K. V. and Spurr, R. J. D.: Ring effect studies: Rayleigh scattering, including molecular parameters for rotational Raman scattering, and the Fraunhofer spectrum, Appl. Optics, 36, 52245230, 1997.

Clémer, K., Fayt, C., Hendrick, F., Hermans, C., Pinardi, G., and Van Roozendael, M.: The simultaneous retrieval of tropospheric aerosol extinction and $\mathrm{NO}_{2}$ vertical profiles from MAXDOAS measurements in Beijing, in: Proceedings of the 8th International Symposium on Tropospheric Profiling, 19-23 October 2009, Delft, The Netherlands, 2009. 
Clémer, K., Van Roozendael, M., Fayt, C., Hendrick, F., Hermans, C., Pinardi, G., Spurr, R., Wang, P., and De Mazière, M.: Multiple wavelength retrieval of tropospheric aerosol optical properties from MAXDOAS measurements in Beijing, Atmos. Meas. Tech., 3, 863-878, doi:10.5194/amt-3-863-2010, 2010.

Curci, G., Palmer, P. I., Kurosu, T. P., Chance, K., and Visconti, G.: Estimating European volatile organic compound emissions using satellite observations of formaldehyde from the Ozone Monitoring Instrument, Atmos. Chem. Phys., 10, 11501-11517, doi:10.5194/acp-10-11501-2010, 2010.

Daumont, M., Brion, J., Charbonnier, J., and Malicet, J.: Ozone UV spectroscopy, I: Absorption cross-sections at room temperature, J. Atmos. Chem., 15, 145-155, 1992.

Demoulin, P., Zander, R., Melen, F., Mahieu, E., and Servais, C.: Column abundance measurements of formaldehyde above the Jungfraujoch, in: Proceedings of "Atmospheric Spectroscopy Applications 1999”, 1-3 September 1999, Reims, France, 59-62, 1999.

De Smedt, I.: Long-Term Global Observations of Tropospheric Formaldehyde Retrieved from Spaceborne Nadir UV Sensors, $\mathrm{PhD}$ Thesis, ULB - Université Libre de Bruxelles, Brussels, 2011.

De Smedt, I., Müller, J.-F., Stavrakou, T., van der A, R., Eskes, H., and Van Roozendael, M.: Twelve years of global observations of formaldehyde in the troposphere using GOME and SCIAMACHY sensors, Atmos. Chem. Phys., 8, 4947-4963, doi:10.5194/acp-8-4947-2008, 2008.

De Smedt, I., Stavrakou, T., Müller, J.-F., Hao, N., Valks, P., Loyola, D., and Van Roozendael, M.: $\mathrm{H}_{2} \mathrm{CO}$ columns retrieved from GOME-2: first scientific results and progress towards the development of an operational product, in: Proceedings of the 2009 EUMETSAT Meteorological Satellite Conference, 2025 September 2009, Bath, UK, 2009.

De Smedt, I., Stavrakou, T., Müller, J.-F., van Der A, R. J., and Van Roozendael, M.: Trend detection in satellite observations of formaldehyde tropospheric columns, Geophys. Res. Lett., 37, L18808, doi:10.1029/2010GL044245, 2010.

Fleischmann, O. C., Hartmann, M., Burrows, J. P., and Orphal, J.: New ultraviolet absorption cross-sections of $\mathrm{BrO}$ at atmospheric temperatures measured by time-windowing Fourier transform spectroscopy, J. Photochem. Photobiol. A, 168, 117-132, 2004.

Fraser, A., Adams, C., Drummond, J. R., Goutail, F., Manney, G., and Strong, K.: The Polar Environment Atmospheric Research Laboratory UV-Visible Ground-Based Spectrometer: First Measurements of $\mathrm{O}_{3}, \mathrm{NO}_{2}, \mathrm{BrO}$, and OClO Columns. J. Quant. Spectrosc. Ra., 110, 986-1004, doi:10.1016/j.jqsrt.2009.02.034, 2009.

Fried, A., Cantrell, C., Olson, J., Crawford, J. H., Weibring, P., Walega, J., Richter, D., Junkermann, W., Volkamer, R., Sinreich, R., Heikes, B. G., O'Sullivan, D., Blake, D. R., Blake, N., Meinardi, S., Apel, E., Weinheimer, A., Knapp, D., Perring, A., Cohen, R. C., Fuelberg, H., Shetter, R. E., Hall, S. R., Ullmann, K., Brune, W. H., Mao, J., Ren, X., Huey, L. G., Singh, H. B., Hair, J. W., Riemer, D., Diskin, G., and Sachse, G.: Detailed comparisons of airborne formaldehyde measurements with box models during the 2006 INTEX-B and MILAGRO campaigns: potential evidence for significant impacts of unmeasured and multigeneration volatile organic carbon compounds, Atmos. Chem. Phys., 11, 11867-11894, doi:10.5194/acp-11-11867-2011, 2011.
Frieß, U., Monks, P. S., Remedios, J. J., Rozanov, A., Sinreich, R., Wagner, T., and Platt, U.: MAX-DOAS $\mathrm{O}_{4}$ measurements: a new technique to derive information on atmospheric aerosols: 2. Modeling studies, J. Geophys. Res., 111, D14203, doi:10.1029/2005JD006618, 2006.

Frieß, U., Sihler, H., Sander, R., Pöhler, D., Yilmaz, S., and Platt, U.: The vertical distribution of $\mathrm{BrO}$ and aerosols in the Arctic: Measurements by active and passive differential optical absorption spectroscopy, J. Geophys. Res., 116, D00R04, doi:10.1029/2011JD015938, 2011.

Grainger, J. F. and Ring, J.: Anomalous Fraunhofer line profiles, Nature, 193, 762, doi:10.1038/193762a0, 1962.

Greenblatt, G. D., Orlando, J. J., Burkholder, J. B., and Ravishankara, A. R.: Absorption measurements of oxygen between 330 and 1140 nm, J. Geophys. Res., 95, 18577-18582, 1990.

Hak, C., Pundt, I., Trick, S., Kern, C., Platt, U., Dommen, J., Ordóñez, C., Prévôt, A. S. H., Junkermann, W., Astorga-Lloréns, C., Larsen, B. R., Mellqvist, J., Strandberg, A., Yu, Y., Galle, B., Kleffmann, J., Lörzer, J. C., Braathen, G. O., and Volkamer, R.: Intercomparison of four different in-situ techniques for ambient formaldehyde measurements in urban air, Atmos. Chem. Phys., 5, 2881-2900, doi:10.5194/acp-5-2881-2005, 2005.

Heckel, A., Richter, A., Tarsu, T., Wittrock, F., Hak, C., Pundt, I., Junkermann, W., and Burrows, J. P.: MAX-DOAS measurements of formaldehyde in the Po-Valley, Atmos. Chem. Phys., 5, 909918, doi:10.5194/acp-5-909-2005, 2005.

Hendrick, F., Van Roozendael, M., Kylling, A., Petritoli, A., Rozanov, A., Sanghavi, S., Schofield, R., von Friedeburg, C., Wagner, T., Wittrock, F., Fonteyn, D., and De Mazière, M.: Intercomparison exercise between different radiative transfer models used for the interpretation of ground-based zenith-sky and multi-axis DOAS observations, Atmos. Chem. Phys., 6, 93-108, doi:10.5194/acp-6-93-2006, 2006.

Herman, J., Cede, A., Spinei, E., Mount, G., Tzortziou, M., and Abuhassan, $\mathrm{N}$.: $\mathrm{NO}_{2}$ column amounts from ground-based Pandora and MFDOAS spectrometers using the direct-sun DOAS technique: Intercomparisons and application to OMI validation, J. Geophys. Res., 114, D13307, doi:10.1029/2009JD011848, 2009.

Hermans, C., Vandaele, A. C., Fally, S., Carleer, M., Colin, R., Coquart, B., Jenouvrier, A., and Mérienne, M.-F.: Absorption crosssection of the collision-induced bands of oxygen from the UV to the NIR, in: Proceedings of the NATO Advanced Research Workshop, Weakly Interacting Molecular Pairs: Unconventional Absorbers of Radiation in the Atmosphere, Fontevraud, France, 24 April-2 May 2002, edited by: Camy-Peyret, C. and Vigasin, A. A., NATO Science Series IV Earth and Environmental Sciences, vol. 27, Kluwer Academic Publishers, Boston, 193-202, 2003.

Hönninger, G., von Friedeburg, C., and Platt, U.: Multi axis differential optical absorption spectroscopy (MAX-DOAS), Atmos Chem. Phys., 4, 231-254, doi:10.5194/acp-4-231-2004, 2004.

Inomata, S., Tanimoto, H., Kameyama, S., Tsunogai, U., Irie, H., Kanaya, Y., and Wang, Z.: Technical Note: Determination of formaldehyde mixing ratios in air with PTR-MS: laboratory experiments and field measurements, Atmos. Chem. Phys., 8, 273 284, doi:10.5194/acp-8-273-2008, 2008. 
Irie, H., Kanaya, Y., Akimoto, H., Iwabuchi, H., Shimizu, A., and Aoki, K.: First retrieval of tropospheric aerosol profiles using MAX-DOAS and comparison with lidar and sky radiometer measurements, Atmos. Chem. Phys., 8, 341-350, doi:10.5194/acp-8341-2008, 2008.

Irie, H., Kanaya, Y., Akimoto, H., Iwabuchi, H., Shimizu, A., and Aoki, K.: Dual-wavelength aerosol vertical profile measurements by MAX-DOAS at Tsukuba, Japan, Atmos. Chem. Phys., 9, 2741-2749, doi:10.5194/acp-9-2741-2009, 2009.

Irie, H., Takashima, H., Kanaya, Y., Boersma, K. F., Gast, L., Wittrock, F., Brunner, D., Zhou, Y., and Van Roozendael, M.: Eightcomponent retrievals from ground-based MAX-DOAS observations, Atmos. Meas. Tech., 4, 1027-1044, doi:10.5194/amt-41027-2011, 2011.

Jones, N. B., Riedel, K., Allan, W., Wood, S., Palmer, P. I., Chance, K., and Notholt, J.: Long-term tropospheric formaldehyde concentrations deduced from ground-based fourier transform solar infrared measurements, Atmos. Chem. Phys., 9, 7131-7142, doi:10.5194/acp-9-7131-2009, 2009.

Li, X., Brauers, T., Shao, M., Garland, R. M., Wagner, T., Deutschmann, T., and Wahner, A.: MAX-DOAS measurements in southern China: retrieval of aerosol extinctions and validation using ground-based in-situ data, Atmos. Chem. Phys., 10, 20792089, doi:10.5194/acp-10-2079-2010, 2010.

Ma, J. Z., Beirle, S., Jin, J. L., Shaiganfar, R., Yan, P., and Wagner, T.: Tropospheric $\mathrm{NO}_{2}$ vertical column densities over Beijing: results of the first three-years of ground-based MAX-DOAS measurements (2008-2011) and satellite validation, Atmos. Chem. Phys. Discuss., 12, 26719-26781, doi:10.5194/acpd-12-267192012, 2012.

Malicet, J., Daumont, D., Charbonnier, J., Parisse, C., Chakir, A., and Brion, J.: Ozone UV spectroscopy, II. Absorption crosssections and temperature dependence, J. Atmos. Chem., 21, 263273, 1995.

Marbach, T., Beirle, S., Platt, U., Hoor, P., Wittrock, F., Richter, A., Vrekoussis, M., Grzegorski, M., Burrows, J. P., and Wagner, T.: Satellite measurements of formaldehyde linked to shipping emissions, Atmos. Chem. Phys., 9, 8223-8234, doi:10.5194/acp9-8223-2009, 2009.

Mayer, B. and Kylling, A.: Technical note: The libRadtran software package for radiative transfer calculations - description and examples of use, Atmos. Chem. Phys., 5, 1855-1877, doi:10.5194/acp-5-1855-2005, 2005.

Meller, R. and Moortgat, G. K.: Temperature dependence of the absorption cross sections of formaldehyde between 223 and $323 \mathrm{~K}$ in the wavelength range $225-375 \mathrm{~nm}, \mathrm{~J}$. Geophys. Res., 105, 7089-7101, 2000.

Millet, D., Jacob, D. J., Turquety, S., Hudman, R. C., Wu, S., Fried, A., Walega, J., Heikes, B. G., Blake, D. R., Singh, H. B., Anderson, B. E., and Clarke, A. D.: Formaldehyde distribution over North America: Implications for satellite retrievals of formaldehyde columns and isoprene emissions, J. Geophys. Res., 111, D24S02, doi:10.1029/2005JD006853, 2006.

Millet, D. B., Jacob, D. J., Boersma, K. F., Fu, T.-M., Kurosu, T. P., Chance, K. V., Heald, C. L., and Guenther, A.: Spatial distribution of isoprene emissions from North America derived from formaldehyde column measurements by the OMI satellite sensor, J. Geophys. Res., 113, 1-18, doi:10.1029/2007JD008950, 2008.
Palmer, P. I., Jacob, D. J., Fiore, A. M., Martin, R. V., Chance, K., and Kurosu, T. P.: Mapping isoprene emissions over North America using formaldehyde column observations from space, J. Geophys. Res., 108, 4180, doi:10.1029/2002JD002153, 2003.

Pikelnaya, O., Hurlock, S. C., Trick, S., and Stutz, J.: Intercomparison of multiaxis and long-path optical absorption spectroscopy measurements in the marine boundary layer, J. Geophys. Res., 112, D10S01, doi:10.1029/2006JD007727, 2007.

Piters, A. J. M., Boersma, K. F., Kroon, M., Hains, J. C., Van Roozendael, M., Wittrock, F., Abuhassan, N., Adams, C., Akrami, M., Allaart, M. A. F., Apituley, A., Beirle, S., Bergwerff, J. B., Berkhout, A. J. C., Brunner, D., Cede, A., Chong, J., Clémer, K., Fayt, C., Frieß, U., Gast, L. F. L., Gil-Ojeda, M., Goutail, F., Graves, R., Griesfeller, A., Großmann, K., Hemerijckx, G., Hendrick, F., Henzing, B., Herman, J., Hermans, C., Hoexum, M., van der Hoff, G. R., Irie, H., Johnston, P. V., Kanaya, Y., Kim, Y. J., Klein Baltink, H., Kreher, K., de Leeuw, G., Leigh, R., Merlaud, A., Moerman, M. M., Monks, P. S., Mount, G. H., Navarro-Comas, M., Oetjen, H., Pazmino, A., Perez-Camacho, M., Peters, E., du Piesanie, A., Pinardi, G., Puentedura, O., Richter, A., Roscoe, H. K., Schönhardt, A., Schwarzenbach, B., Shaiganfar, R., Sluis, W., Spinei, E., Stolk, A. P., Strong, K., Swart, D. P. J., Takashima, H., Vlemmix, T., Vrekoussis, M., Wagner, T., Whyte, C., Wilson, K. M., Yela, M., Yilmaz, S., Zieger, P., and Zhou, Y.: The Cabauw Intercomparison campaign for Nitrogen Dioxide measuring Instruments (CINDI): design, execution, and early results, Atmos. Meas. Tech., 5, 457-485, doi:10.5194/amt-5-457-2012, 2012.

Platt, U. and Stutz, J.: Differential Optical Absorption Spectroscopy, Principles and Applications, Springer, Berlin, 2008.

Roscoe, H. K., Johnston, P. V., Van Roozendael, M., Richter, A., Preston, K., Lambert, J.-C., Hermans, C., de Cuyper, W., Dzenius, S., Winterath, T., Burrows, J., Sarkissian, A., Goutail, F., Pommereau, J.-P., d'Almeida, E., Hottier, J., Coureul, C., Ramond, D., Pundt, I., Bartlet, L. M., Kerr, J. E., Elokhov, A., Giovanelli, G., Ravegnani, F., Premudan, M., Kostadinov, M., Erle, F., Wagner, T., Pfeilsticker, K., Kenntner, M., Marquand, L. C., Gil, M., Puentedura, O., Arlander, W., Kastad-Hoiskar, B. A., Tellefsen, C. W., Heese, C. W., Jones, R. L., Aliwalle, S. R., and Freswater, R. A.: Slant column measurements of $\mathrm{O}_{3}$ and $\mathrm{NO}_{2}$ during the NDSC intercomparison of zenith-sky UVvisible spectrometers in June 1996, J. Atmos. Chem., 32, 281314, 1999.

Roscoe, H. K., Van Roozendael, M., Fayt, C., du Piesanie, A., Abuhassan, N., Adams, C., Akrami, M., Cede, A., Chong, J., Clémer, K., Friess, U., Gil Ojeda, M., Goutail, F., Graves, R., Griesfeller, A., Grossmann, K., Hemerijckx, G., Hendrick, F., Herman, J., Hermans, C., Irie, H., Johnston, P. V., Kanaya, Y., Kreher, K., Leigh, R., Merlaud, A., Mount, G. H., Navarro, M., Oetjen, H., Pazmino, A., Perez-Camacho, M., Peters, E., Pinardi, G., Puentedura, O., Richter, A., Schönhardt, A., Shaiganfar, R., Spinei, E., Strong, K., Takashima, H., Vlemmix, T., Vrekoussis, M., Wagner, T., Wittrock, F., Yela, M., Yilmaz, S., Boersma, F., Hains, J., Kroon, M., Piters, A., and Kim, Y. J.: Intercomparison of slant column measurements of $\mathrm{NO}_{2}$ and $\mathrm{O}_{4}$ by MAX-DOAS and zenith-sky UV and visible spectrometers, Atmos. Meas. Tech., 3, 1629-1646, doi:10.5194/amt-3-1629-2010, 2010. 
Russchenberg, H., Bosveld, F., Swart, D., ten Brink, H., de Leeuw, G., Uijlenhoet, R., Abresser-Rastburg, B., van der Marel, H., Ligthart, L., Boers, R., and Apituley, A.: Groundbased atmospheric remote sensing in The Netherlands; European outlook, IEICE T. Commun., E88-B, 2252-2258, doi:10.1093/ietcom/e88-b.6.2252, 2005.

Shaiganfar, R., Beirle, S., Sharma, M., Chauhan, A., Singh, R. P., and Wagner, T.: Estimation of $\mathrm{NO}_{\mathrm{x}}$ emissions from Delhi using Car MAX-DOAS observations and comparison with OMI satellite data, Atmos. Chem. Phys., 11, 10871-10887, doi:10.5194/acp-11-10871-2011, 2011.

Sinreich, R., Friess, U., Wagner, T., and Platt, U.: Multi axis differential optical absorption spectroscopy (MAX-DOAS) of gas and aerosol distributions, Faraday Discuss., 130, 153-164, 2005.

Sinreich, R., Volkamer, R., Filsinger, F., Frieß, U., Kern, C., Platt, U., Sebastián, O., and Wagner, T.: MAX-DOAS detection of glyoxal during ICARTT 2004, Atmos. Chem. Phys., 7, 1293-1303, doi:10.5194/acp-7-1293-2007, 2007.

Stavrakou, T., Müller, J.-F., De Smedt, I., Van Roozendael, M., van der Werf, G. R., Giglio, L., and Guenther, A.: Evaluating the performance of pyrogenic and biogenic emission inventories against one decade of space-based formaldehyde columns, Atmos. Chem. Phys., 9, 1037-1060, doi:10.5194/acp-9-1037-2009, 2009a.

Stavrakou, T., Müller, J.-F., De Smedt, I., Van Roozendael, M., van der Werf, G. R., Giglio, L., and Guenther, A.: Global emissions of non-methane hydrocarbons deduced from SCIAMACHY formaldehyde columns through 2003-2006, Atmos. Chem. Phys., 9, 3663-3679, doi:10.5194/acp-9-3663-2009, 2009b.

Stutz, J. and Platt, U.: Numerical analysis and error estimation of differential optical absorption spectroscopy measurements with least-squares methods, Appl. Optics, 35, 6041-6053, 1996.

Theys, N., Van Roozendael, M., Hendrick, F., Fayt, C., Hermans, C., Baray, J.-L., Goutail, F., Pommereau, J.-P., and De Mazière, M.: Retrieval of stratospheric and tropospheric $\mathrm{BrO}$ columns from multi-axis DOAS measurements at Reunion Island $\left(21^{\circ} \mathrm{S}\right.$, $56^{\circ}$ E), Atmos. Chem. Phys., 7, 4733-4749, doi:10.5194/acp-74733-2007, 2007.

Theys, N., Van Roozendael, M., Hendrick, F., Yang, X., De Smedt, I., Richter, A., Begoin, M., Errera, Q., Johnston, P. V., Kreher, K., and De Mazière, M.: Global observations of tropospheric BrO columns using GOME-2 satellite data, Atmos. Chem. Phys., 11, 1791-1811, doi:10.5194/acp-11-1791-2011, 2011.

Van Roozendael, M., Fayt, C., Post, P., Hermans, C., and Lambert, J.-C.: Retrieval of $\mathrm{BrO}$ and $\mathrm{NO}_{2}$ from UV-Visible observations, in: Sounding the Troposphere from Space: a New Era for Atmospheric Chemistry, edited by: Borrell, P. M., Burrows, J. P., and Platt, U., Springer, Heidelberg, 155-165, 2003.

Vandaele, A. C., Hermans, C., Simon, P. C., Van Roozendael, M., Guilmot, J. M., Carleer, M., and Colin, R.: Fourier transform measurement of $\mathrm{NO}_{2}$ absorption cross-section in the visible range at room temperature, J. Atmos. Chem., 25, 289-305, 1996.

Vandaele, A. C., Fayt, C., Hendrick, F., Hermans, C., Humbled, F., Van Roozendael, M., Gil, M., Navarro, M., Puentedura, O., Yela, M., Braathen, G., Stebel, K., Tørnkvist, K., Johnston, P., Kreher, K., Goutail, F., Mieville, A., Pommereau, J.-P., Khaikine, S., Richter, A., Oetjen, H., Wittrock, F., Bugarski, S., Friess, U., Pfeilsticker, K., Sinreich, R., Wagner, T., Corlett, G., and Leigh,
R.: An intercomparison campaign of ground-based UV-visible measurements of $\mathrm{NO}_{2}, \mathrm{BrO}$, and $\mathrm{OClO}$ slant columns: Methods of analysis and results for $\mathrm{NO}_{2}$, J. Geophys. Res., 110, D08305, doi:10.1029/2004JD005423, 2005.

Vigouroux, C., Hendrick, F., Stavrakou, T., Dils, B., De Smedt, I., Hermans, C., Merlaud, A., Scolas, F., Senten, C., Vanhaelewyn, G., Fally, S., Carleer, M., Metzger, J.-M., Müller, J.-F., Van Roozendael, M., and De Mazière, M.: Ground-based FTIR and MAX-DOAS observations of formaldehyde at Réunion Island and comparisons with satellite and model data, Atmos. Chem. Phys., 9, 9523-9544, doi:10.5194/acp-9-9523-2009, 2009.

Vlemmix, T., Piters, A. J. M., Stammes, P., Wang, P., and Levelt, P. F.: Retrieval of tropospheric $\mathrm{NO}_{2}$ using the MAX-DOAS method combined with relative intensity measurements for aerosol correction, Atmos. Meas. Tech., 3, 1287-1305, doi:10.5194/amt-31287-2010, 2010.

Vlemmix, T., Piters, A. J. M., Berkhout, A. J. C., Gast, L. F. L., Wang, P., and Levelt, P. F.: Ability of the MAX-DOAS method to derive profile information for $\mathrm{NO}_{2}$ : can the boundary layer and free troposphere be separated?, Atmos. Meas. Tech., 4, 26592684, doi:10.5194/amt-4-2659-2011, 2011a.

Vlemmix, T., Eskes, H. J., Piters, A. J. M., Kelder, H., and Levelt, P. F.: MAX-DOAS tropospheric nitrogen dioxide column measurements compared with the Lotos-Euros air quality model, Atmos. Chem. Phys. Discuss., 11, 28895-28944, doi:10.5194/acpd-1128895-2011, 2011 b.

Vogel, L., Sihler, H., Lampel, J., Wagner, T., and Platt, U.: Retrieval interval mapping, a tool to optimize the spectral retrieval range in differential optical absorption spectroscopy, Atmos. Meas. Tech. Discuss., 5, 4195-4247, doi:10.5194/amtd-5-4195-2012, 2012.

Vountas, M., Rozanov, V. V., and Burrows, J. P.: Ring effect: Impact of rotational Raman scattering on radiative transfer in earth's atmosphere, J. Quant. Spectrosc. Ra., 60, 943-961, 1998.

Vrekoussis, M., Wittrock, F., Richter, A., and Burrows, J. P.: GOME-2 observations of oxygenated VOCs: what can we learn from the ratio glyoxal to formaldehyde on a global scale?, Atmos. Chem. Phys., 10, 10145-10160, doi:10.5194/acp-1010145-2010, 2010.

Wagner, T., von Friedeburg, C., Wenig, M., Otten, C., and Platt, U.: UV-visible observations of atmospheric $\mathrm{O}_{4}$ absorptions using direct moonlight and zenith-scattered sunlight for clear-sky and cloudy sky conditions, J. Geophys. Res., 107, D204424, doi:10.1029/2001JD001026, 2002.

Wagner, T., Dix, B., Friedeburg, C. V., Frieß, U., Sanghavi, S., Sinreich, R., and Platt, U.: MAX-DOAS $\mathrm{O}_{4}$ measurements - a new technique to derive information on atmospheric aerosols, (I) Principles and information content, J. Geophys. Res., 109, D22205, doi:10.1029/2004JD004904, 2004.

Wagner, T., Beirle, S., and Deutschmann, T.: Three-dimensional simulation of the Ring effect in observations of scattered sun light using Monte Carlo radiative transfer models, Atmos. Meas. Tech., 2, 113-124, doi:10.5194/amt-2-113-2009, 2009.

Wagner, T., Beirle, S., Brauers, T., Deutschmann, T., Frieß, U., Hak, C., Halla, J. D., Heue, K. P., Junkermann, W., Li, X., Platt, U., and Pundt-Gruber, I.: Inversion of tropospheric profiles of aerosol extinction and $\mathrm{HCHO}$ and $\mathrm{NO}_{2}$ mixing ratios from MAX-DOAS observations in Milano during the summer of 2003 and comparison with independent data sets, Atmos. Meas. Tech. Discuss., 4, 3891-3964, doi:10.5194/amtd-4-3891-2011, 2011. 
Wilmouth, D. M., Hanisco, T. F., Donahue, N. M., and Anderson, J. G.: Fourier transform ultraviolet spectroscopy of the A(2_3/2)_(2_3/2) transition of BrO, J. Phys. Chem., 103, 89358944, 1999.

Wittrock, F., Oetjen, H., Richter, A., Fietkau, S., Medeke, T., Rozanov, A., and Burrows, J. P.: MAX-DOAS measurements of atmospheric trace gases in Ny-Ålesund - Radiative transfer studies and their application, Atmos. Chem. Phys., 4, 955-966, doi:10.5194/acp-4-955-2004, 2004.

Wittrock, F., Richter, A., Oetjen, H., Burrows, J. P., Kanakidou, M., Myriokefalitakis, S., Volkamer, R., Beirle, S., Platt, U., and Wagner, T.: Simultaneous global observations of glyoxal and formaldehyde from space, Geophys. Res. Lett., 33, L16804, doi:10.1029/2006g1026310, 2006.
Zieger, P., Weingartner, E., Henzing, J., Moerman, M., de Leeuw, G., Mikkilä, J., Ehn, M., Petäjä, T., Clémer, K., van Roozendael, M., Yilmaz, S., Frieß, U., Irie, H., Wagner, T., Shaiganfar, R., Beirle, S., Apituley, A., Wilson, K., and Baltensperger, U.: Comparison of ambient aerosol extinction coefficients obtained from in-situ, MAX-DOAS and LIDAR measurements at Cabauw, Atmos. Chem. Phys., 11, 2603-2624, doi:10.5194/acp11-2603-2011, 2011. 